University of Pennsylvania Carey Law School

Penn Law: Legal Scholarship Repository

Faculty Scholarship at Penn Law

6-2007

\title{
Of Equal Wrongs and Half Rights
}

\author{
Gideon Parchomovsky \\ University of Pennsylvania Carey Law School \\ Peter Siegelman \\ University of Connecticut Law School \\ Steven Thel \\ Fordham University School of Law
}

Follow this and additional works at: https://scholarship.law.upenn.edu/faculty_scholarship

Part of the Common Law Commons, Contracts Commons, Ethics and Political Philosophy Commons, Jurisprudence Commons, Property Law and Real Estate Commons, and the Torts Commons

\section{Repository Citation}

Parchomovsky, Gideon; Siegelman, Peter; and Thel, Steven, "Of Equal Wrongs and Half Rights" (2007). Faculty Scholarship at Penn Law. 112.

https://scholarship.law.upenn.edu/faculty_scholarship/112

This Article is brought to you for free and open access by Penn Law: Legal Scholarship Repository. It has been accepted for inclusion in Faculty Scholarship at Penn Law by an authorized administrator of Penn Law: Legal Scholarship Repository. For more information, please contact PennlawIR@law.upenn.edu. 


\title{
OF EQUAL WRONGS AND HALF RIGHTS
}

\author{
Gideon Parchomovsky, Peter Siegelman \& Steve Thel*
}

With a tiny handful of exceptions, common law jurisprudence is predicated on a "winner-take-all" principle: The plaintiff either gets the entire entitlement at issue or collects nothing at all. Cases that split an entitlement between the two parties are exceedingly rare. While there may be sound reasons for the all-or-nothing rule, in this Article we argue that there is a limited but important set of property, torts, and contracts cases in which an equal division of an entitlement should be adopted. The common element in these cases is a windfall-a gain or loss that occurs despite the fact that no effort to promote, prevent, or allocate it ex ante would be cost-justified or reasonable. We show that an equal division of disputed windfalls promotes both efficiency and fairness and also has the virtue of clarifying several tortured legal doctrines.

We also address and reject the standard objections to split-the-difference remedies. We demonstrate that the introduction of a splitting option is unlikely to distort judicial incentives, and that it is likely to improve the integrity of the judicial system. Counterintuitively, we show that giving judges the option to order a compromise remedy in windfall disputes is likely to reduce judicial error, rather than increase it, and that the valuation problems that attend the introduction of a split-the-difference rule are insignificant.

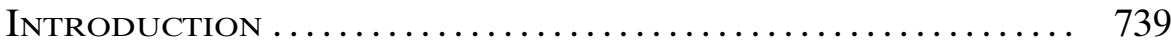

I. Intellectual History ............................ 747

II. Defining Windfalls ............................ 753

A. The Windfall Problem ...................... 754

B. Defining Windfalls ........................... 755

III. The Normative Case for a Split-the-Difference

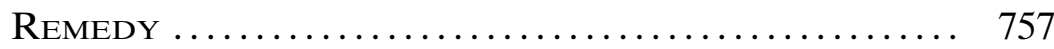

A. Efficiency: Splitting the Difference Provides Valuable Insurance ........................ 757

B. Splitting the Difference is Fair................. 761

IV. Doctrinal Integrity ...................... 763

A. Mutual Mistake .......................... 765

B. Ambiguous Commitment..................... 767

$\mathbf{R}$

$\mathbf{R}$

$\mathbf{R}$

$\mathbf{R}$

$\mathbf{R}$

$\mathbf{R}$

$\mathbf{R}$

$\mathbf{R}$

$\mathbf{R}$

$\mathbf{R}$

$\mathbf{R}$

* Copyright (C) 2007 by Gideon Parchomovsky, Peter Siegelman, and Steve Thel. Gideon Parchomovosky is a Professor at the University of Pennsylvania Law School and a Visiting Professor with the Bar Ilan University Faculty of Law. Peter Siegelman is the Roger Sherman Professor of Law at the University of Connecticut School of Law. Steve Thel is the I. Maurice Wormser Professor of Law at Fordham Law School. This Article greatly benefited from the comments and criticisms of Michael Abramowicz, Tom Baker, Avi Bell, Omri Ben-Shahar, Bethany Berger, Yoav Dotan, Michael Fischl, Amanda Goodin, Alon Harel, James Krier, Alexandra Lahav, Paul Monteleoni, Jeremy Paul, Adam Scales, Ben Zipursky and seminar participants at Fordham Law School, the Israel Law \& Economics Association, and the University of Connecticut School of Law. 
C. Impracticability and Frustration of Purpose ........ 768

D. Found Property .......................... 770

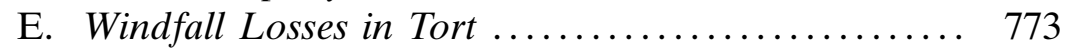

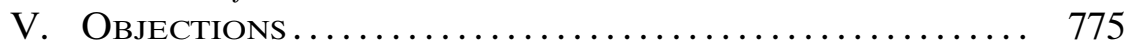

A. Judicial Incentives ............................. 775

$\mathbf{R}$

1. Will the Availability of Splitting Lead Judges to

Slack Off? ............................. 776

2. Error Creation or Error Correction?.......... 776

a. Errors Under the Status Quo............ 778

b. Errors Under Splitting................. 779

B. The Integrity of the Judicial System ............ 781

C. Apportionment: Variable Splitting, Redistribution, and Insurance......................... 782

D. Force Majeure Clauses and Contractual Solutions to the Windfall Problem ..................... 784

E. Valuation Problems .................... 787

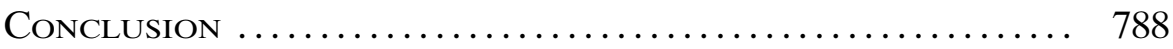

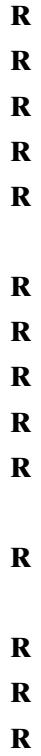

INTRODUCTION

In one of the most famous property disputes of this young century, a court was asked to determine ownership of a baseball. This was no ordinary ball, however. Seconds before the dispute arose, the ball had been hit into the stands by Barry Bonds, thereby breaking Major League Baseball's single-season home run record. At the end of its flight, the ball landed in the glove of an elated fan, Alex Popov. But Mr. Popov's joy proved to be short-lived. A group of fans, also in pursuit of the ball, jostled Popov, causing him to drop it. In the ensuing mayhem, Patrick Hayashi, who had been knocked to the ground in the stampede, wound up with the ball. Before long, the two fans met again in court, when Popov brought a lawsuit against Hayashi to get the ball back. ${ }^{1}$

1 Popov v. Hayashi, No. 400545, 2002 WL 31833731, at*1-2 (Cal. Super. Ct. Dec. 18, 2002). The complaint listed various causes of action including trespass to chattel and conversion. $I d$. at $* 3$. The case has attracted considerable scholarly commentary, with predictably diverse views. See, e.g., Paul Finkelman, Fugitive Baseballs and Abandoned Property: Who Owns the Home Run Ball?, 23 CARdozo L. Rev. 1609, 1631-32 (2002) (arguing for awarding ball to whoever first catches it so as to prevent dangerous behavior by fans); Steven Semeraro, An Essay on Property Rights in Milestone Home Run Baseballs, 56 SMU L. REV. 2281, 2283 (2003) (suggesting that instrumental goals of protecting public safety and minimizing litigation "weigh strongly in favor of ... placing the superior property right to a milestone home run baseball in either the home team that originally owned it or the batter who increased its value, rather than in the fan who caught it"); Michael Pastrick, Note, When a Day at the Ballpark Turns a "Can of Corn" into a Can of Worms: Popov v. Hayashi, 51 Buff. L. Rev. 905 (2003) (arguing case was correctly decided and that its equitable division approach should be more widely applied); Patrick Stoklas, Comment, 


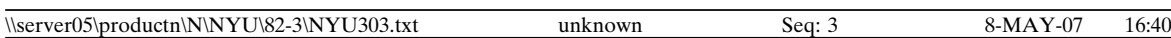

A Pierson v. Post ${ }^{2}$ for the twenty-first century, this case has all the makings of another property classic. ${ }^{3}$ In Pierson, as all first-year law students know, the court ruled that ownership of a wild animal may be established through physical capture, mortal wounding, or trapping; mere pursuit or reasonable prospect of capture of the animal does not suffice. ${ }^{4}$ Importantly, the rule of capture or first possession established in Pierson has since been extended to other fugitive resources, including inanimate ones. ${ }^{5}$ Based on these precedents, one would have expected the Popov court to award ownership of the disputed baseball to the first party who established possession. Surprisingly, however, after viewing a videotape that captured the entire incident, the court deviated from the Pierson line of cases and instead decreed that the ball should be auctioned off, with the proceeds to be divided equally between the two claimants. ${ }^{6}$

While the Popov decision is perhaps consistent with folk intuition, it is in many ways a striking legal anomaly. Property, contracts, and torts casebooks are replete with dichotomous cases in which the plaintiff either receives her requested remedy or is denied relief altogether. Split-the-difference remedies are exceedingly unusual. The scarcity of compromise remedies is puzzling. As we demonstrate in this Article, a split-the-difference remedy can effect a more efficient and more just result in many classes of property, contracts, and torts disputes, and its use should be extended. To illustrate this point, we will discuss the advantages of a split-the-difference remedy in the context of three classic cases from contract, tort, and property law: Sherwood v. Walker, ${ }^{7}$ Vosberg v. Putney, ${ }^{8}$ and O'Keeffe v. Snyder. ${ }^{9}$

Popov v. Hayashi, a Modern Day Pierson v. Post: A Comment on What the Court Should Have Done with the Seventy-third Home Run Baseball Hit by Barry Bonds, 34 Loy. U. CHI. L.J. 901, 937-38 (2003) (concluding that ball should have been awarded to Hayashi as one who "stopped the momentum of the baseball and brought it under his control").

23 Cai. 175 (N.Y. Sup. Ct. 1805).

3 See Stoklas, supra note 1, at 901 (calling Popov a "[m]odern [d]ay Pierson v. Post").

4 Pierson, 3 Cai. at 178 . For a compelling reframing of the case arguing that what was really at stake was access to common property rather than entitlement to the disputed animal, see Bethany R. Berger, It's Not About the Fox, 55 Duke L.J. 1089 (2006).

5 See Jesse Dukeminier et al., Property 33 (6th ed. 2006) (discussing application of rule of capture to oil and gas).

6 Popov, 2002 WL 31833731, at *8.

733 N.W. 919 (Mich. 1887) (holding that mutual mistake about infertility of cow voided contract for sale).

856 N.W. 480 (Wis. 1893) (holding that defendant's wrongful kick subjected him to liability for all consequences of his intentional tort, including those unforeseeable to either party at time of kick).

9416 A.2d 862 (N.J. 1980) (finding plaintiff, as true owner, entitled to recover stolen paintings even if defendant had purchased them in good faith from third party). 


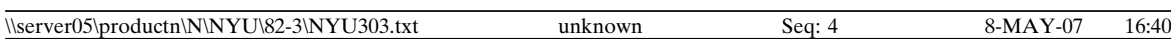

In Sherwood, the plaintiff contracted to buy a cow-Rose $2 \mathrm{~d}$ of Aberlone-from the defendants. ${ }^{10}$ Both parties reasonably assumed that Rose was barren, leaving her best commercial use as slaughter for beef. The contract between the parties reflected this assumption by setting a low price for the cow and denominating the price on a perpound basis, a method used exclusively for cattle destined for slaughter. After the parties agreed to the sale, but before the cow was delivered, it became apparent that she was pregnant. Naturally, this happy development substantially raised the market value of the cowin this case, by a factor of ten. Upon learning the news, however, the seller refused to part with the cow. The buyer then brought an action for replevin. The court ruled that if the cow had been sold based on the assumption that it was barren, and it was later discovered that she was fertile, the seller could refuse to deliver and rescind the contract on the grounds of mutual mistake. ${ }^{11}$

Sherwood is often invoked as the quintessential mistake case, ${ }^{12}$ although one might question this conclusion. ${ }^{13}$ But assuming that there was a mistake, the court then faced a classic windfall problem, ${ }^{14}$ a problem that it completely failed to acknowledge: Who should get the additional value arising from the cow's unexpected fertility? By allowing the seller to keep the cow, the court gave him all of the additional value. The dissent's conclusion that there was no mistake ${ }^{15}$ would have allocated the entire windfall to the buyer. We propose that as a matter of both efficiency and fairness, the value should have been split between the parties. Ex ante, the likelihood of the cow being fertile was very low and thus did not justify a contractual provision for this contingency. This in turn implies that there was no principled reason to favor either party and many reasons to share the windfall on fairness grounds. Moreover, as we will show, splitting the windfall would not have affected the parties' ex ante incentives to bar-

10 Sherwood, 33 N.W. at 919-21.

11 Id. at 923-24. Note that the precise rules for determining mutual mistake articulated in Sherwood were later overturned by the Michigan Supreme Court in Lenawee County Board of Health v. Messerly, 331 N.W.2d 203, 209 (Mich. 1982) (requiring that mistake "relate[ ] to a basic assumption of the parties upon which the contract is made").

12 See, e.g., Lenawee County, 331 N.W.2d at 208 (discussing Sherwood).

13 The Sherwood dissent strongly suggested that there was no mistake but simply a difference in predictions, or what amounted to a bet. 33 N.W. at 925 . It might be significant that the disappointed buyer never argued that he was buying the cow "on spec," which would have made the dissent's characterization more apposite.

14 The concept of windfalls is crucial to this Article's argument, and we discuss our definition and its implementation at length below. For now, it suffices to think of windfalls as events that create a benefit or loss, are unforeseeable, and involve no effort or planning by any party.

15 Sherwood, 33 N.W. at 924. 
gain for the risk, check the cow's status, or otherwise alter their behavior. Finally, a splitting rule has favorable risk-aversion or insurance properties, as we will demonstrate.

Next consider the famous case of Vosburg v. Putney. ${ }^{16}$ There, the defendant, a schoolboy, "reached across the aisle with his foot, and hit with his toe the shin of the right leg of the plaintiff. The touch was slight." 17 Notwithstanding the slightness of the touch, the event precipitated a parade of horribles, ultimately resulting in the plaintiff losing the use of his limb. The court admitted that it would have been hesitant to find the defendant liable if the touching had occurred on the playground; however, since the incident occurred in class and in violation of school rules, the court found the defendant liable for all of the wholly unexpected and unintended damage suffered by the plaintiff. $^{18}$ This case is credited with establishing the famous "eggshell skull" principle, according to which the defendant must accept the plaintiff as he is, making the defendant responsible for all the consequences of her actions, whether foreseeable or not. ${ }^{19}$ We argue that a better approach would be to apply the split-the-difference principle to the portion of the damage in excess of the usual harm caused by a slight touch between two schoolchildren. ${ }^{20}$ Again, we advance two reasons in support of our argument. First, since the unusual portion of the harm is so unforeseeable, its allocation between the parties will have no ex ante effect on their behavior: Leaving the loss with the plaintiff would not cause him to take more precautions, and shifting it to the defendant would not result in fewer "slight touches" in schools. Second, since the loss is completely unforeseeable and noncon-

16 The complex facts of the case have been exhaustively reported in Zigurds L. Zile, Vosburg v. Putney: A Centennial Story, 1992 Wis. L. REv. 877. Zile notes that the case was actually tried three different times, with only the final verdict withstanding the scrutiny of the Wisconsin Supreme Court. Id. at 978. He wonders, almost in passing, whether "anything [should] be made of the circumstance that the jurors in each case awarded to the plaintiff an amount which was almost exactly ... half the amount demanded?" Id. at 979. Thus, it appears as if Vosburg may actually have been an (unofficial) split-the-difference case after all, even if it is not so described in the judicial opinion that students typically read. We take this fact as confirming our intuitions about the appropriate remedy.

It is also clear from Zile's evidence, however, that both the victim's family and-most likely-the kicker himself did know something about Andrew Vosburg's fragile leg, which had been injured some years earlier in an accident involving an axe. Id. at 879. To the extent that either party knew of the leg's fragility and could have done something to prevent its further injury, this weighs against a split-the-difference remedy.

17 Vosburg v. Putney, 47 N.W. 99, 99 (Wis. 1890).

18 Vosburg v. Putney, 50 N.W. 403, 403-04 (Wis. 1891).

19 Id. at 404; see also Zile, supra note 16, at 980 (noting that excerpt from Vosburg's second opinion was included in sequence of "eggshell-skull" cases as early as 1895).

20 In this instance, all of the harm should be split, since a slight touch usually causes no harm at all, and all the harm is therefore "excess." 
tractible, the parties would choose to split it if they were placed behind a veil of ignorance.

Finally, consider the case of O'Keeffe v. Snyder. ${ }^{21}$ The plaintiff, artist Georgia O'Keeffe, sought to recover from the defendant's gallery three paintings she claimed had been stolen almost thirty-five years earlier. ${ }^{22}$ The defendant apparently had bought them in good faith from someone he believed to be their true owner; this belief was reasonable, since O'Keeffe never reported the paintings as missing. ${ }^{23}$ However, the court held that the plaintiff, as the true owner of the paintings, was entitled to recover them from the defendant.

Conflicts between true owners of stolen property and subsequent good-faith purchasers pervade the landscape of property law. American property law chooses to side with the true owner, allowing her to recover the stolen goods even years after the theft has occurred.24 Many European countries, by contrast, favor the purchaser, who, in good faith and for consideration, acquired stolen personal property. ${ }^{25}$ We contend that instead of adopting either of these extreme positions, it would be better to resolve conflicts between true owners and good-faith purchasers by splitting the loss between them. Doing so promotes both efficiency and fairness. ${ }^{26}$ The defendant's good-faith purchaser status implies, by definition, that she could not reasonably know of the true owner's claim to the goods. Hence, the remedy choice will have no effect on her actions. As for the original owner, it can be assumed that, because the likelihood of tracing stolen goods is vanishingly small, splitting the recovery will not affect her investment in precautions to prevent theft.

While at first glance these three cases might seem to have nothing in common, a closer examination reveals that they share an important characteristic: windfalls. Sherwood involved a positive windfall, while Vosberg and O'Keeffe involved negative windfalls. ${ }^{27}$ In all three cases,

21416 A.2d 862 (N.J. 1980).

22 Id. at 864.

23 Id. at 864-66.

24 For example, the O'Keeffe decision made it clear that if the paintings had in fact been stolen, the plaintiff was entitled to recover them as long as she did so within the operative period of limitations. Id. at 874.

25 For an excellent comparative analysis of bona fide purchaser rules, see generally Saul Levmore, Variety and Uniformity in the Treatment of the Good Faith Purchaser, $16 \mathrm{~J}$. LEGAL STUd. 43 (1987).

26 It is noteworthy that O'Keeffe and Snyder ultimately settled the case along the lines of our proposal: They shared the value of the disputed paintings. See Dukeminier et AL., supra note 5, at 154 (noting that O'Keeffe and Snyder took one painting each and shared value of third).

27 Sherwood and Vosberg involve true social windfalls because there was either more or less total social value than either party had anticipated in both cases. O'Keeffe is some- 
the parties did not foresee, and could not reasonably have foreseen, the windfall. Yet, in each of the cases, the court assigned the entire windfall - whether positive or negative- to one of the parties, thereby creating a clear winner and a clear loser. This Article posits that these three cases could have been better resolved with a split-the-difference remedy. Of course, the applicability of the split-the-difference solution is not limited to these three celebrated cases. Rather, it extends to myriad disputes over windfalls, such as those involving impossibility, mutual mistake, and objective ambiguity in contracts; issues of foreseeability and causality in tort law; and good-faith purchasers, finders of lost property, and good-faith improvers in property law.

The normative case for a split-the-difference remedy proceeds on three grounds: efficiency, fairness, and doctrinal integrity. Consider efficiency first. Essentially, the split-the-difference remedy may be viewed as a partial insurance mechanism for judicial decisions allocating windfalls. Given a choice between (1) a fifty percent chance of a $\$ 10,000$ award and a fifty percent chance of $\$ 0$; and (2) a one hundred percent chance of $\$ 5000$, any rational, risk-averse person will prefer the latter. ${ }^{28}$ Thus, when both the plaintiff and the defendant are risk averse and the court is equally likely to come out in either party's favor, both should prefer to split the difference with certainty rather than risk an all-or-nothing outcome. Under these circumstances, therefore, splitting the difference enhances the welfare of both parties relative to all-or-nothing remedies. ${ }^{29}$

As for fairness, splitting the difference is more equitable than an all-or-nothing remedy in windfall cases, where, by definition, the gain or loss cannot justly be allocated to either party. As is evident from the three examples discussed above, an all-or-nothing outcome is inherently arbitrary. In allocating a gain or a loss between two parties who are identical in all relevant respects, policymakers should treat them equally and neither excessively reward nor punish either party. In other words, in true windfall cases, equality should be the guiding principle. Since the parties are necessarily in a symmetrical position

what different in that it has no social windfall-the paintings were always in the possession of someone, be it O'Keeffe, the thief, or the purchaser. Instead, the windfall arises because, as viewed by O'Keeffe, the paintings had been lost and were then recovered (a positive windfall); alternatively, as viewed by the good-faith purchaser, the paintings were bought and subsequently an additional claimant for their ownership was discovered (a negative windfall).

28 As we explain below, the phenomenon of risk aversion derives from the decreasing marginal utility of wealth, which implies that an additional one-dollar increment to one's wealth generates a smaller increase in utility as one's wealth increases. See infra notes 74-78 and accompanying text.

29 We develop this insight at greater length infra Part III.A. 
vis-à-vis the windfall loss or gain, courts invariably struggle to find a rationale for leaving the windfall where it lies or shifting it to the other party. Importantly, equal division does not merely reflect a widely shared fairness intuition. It also represents the equilibrium solution to a hypothetical bargaining game where the surplus created by the bargaining may be realized only if the parties reach an agreement, but not otherwise-and so mirrors the solution that the parties themselves would reach under idealized conditions. ${ }^{30}$

Split-the-difference remedies also enhance doctrinal integrity. The need to make all-or-nothing decisions leads courts to tie themselves in doctrinal knots or to deviate from established legal principles, causing confusion and uncertainty. The high-brow rhetoric of the courts in these situations masks an essentially arbitrary decisionmaking process biased toward letting the loss or gain lie where it fell. ${ }^{31}$ Instead of engaging in unhelpful doctrinal hair splitting, we call on courts, in appropriate circumstances, to abandon the fruitless quest for a single victor-when no such person exists-and to split the difference between the parties. Doing so will not only introduce doctrinal integrity but will also economize on judicial resources and spare judges from the pointed arrows of academic critics.

Naturally, the split-the-difference option must only be exercised in appropriate cases. Therefore, an important contribution of this Article is to point out the limits of the split-the-difference solution. While it is almost always possible, and might be tempting, for courts to divide a contested entitlement in two, we strongly caution against indiscriminate application of equal division. The obvious reason for concern is that inappropriate splitting constitutes a form of judicial error: The decision to award a split remedy when one or the other party should win is wrong and generates a host of negative effects, from a loss of faith in the judicial system to perverse incentives for future conduct and bad precedents.

We assert that the split-the-difference mechanism should only be applied to windfalls: cases of rational ignorance, where the remedy ultimately awarded has no appreciable ex ante incentive effects on future behavior. In Sherwood, for example, there was simply no avail-

\footnotetext{
30 See infra note 86.

31 See, e.g., Wood v. Boynton, 25 N.W. 42, 44-45 (Wis. 1885) (upholding sale of rock that turned out to be diamond because seller acted with consciousness of her own ignorance). Andrew Kull argues that this arbitrariness may be the best we can hope for because at least it avoids any systematic biases. Andrew Kull, Mistake, Frustration, and the Windfall Principle of Contract Remedies, 43 Hastings L.J. 1, 52-54 (1991). It is our claim that splitting the difference is far preferable to an arbitrary remedy in windfall cases. We have also been heavily influenced by Eric Kades, Windfalls, 108 Yale L.J. 1489 (1999). We discuss both Kades and Kull infra notes 57-60, 79, 87-88 and accompanying text.
} 
able technology for conclusively determining whether or not the cow was fertile. Hence, the allocation of the cow-whether to the buyer, the seller, or both of them-could have no effect on the investment decisions of future parties. Likewise, given the apparent certainty with which both parties believed the cow to be barren, we claim that the cost of contractually specifying which party would get the cow, should it prove to be fertile, was larger than the expected benefit from doing so. Thus, there should be no reasonable expectation that in the future, similarly situated parties would alter their contracting decisions as a result of the proposed split.

A similar analysis applies to Vosberg. In that case, neither the tortfeasor nor the victim knew, or reasonably could have known, about the victim's unique medical condition. ${ }^{32}$ Consequently, the ex post damage award could not have influenced the ex ante behavior of the parties. The victim would not have taken any additional precautions even if there were no liability for schoolhouse kicks, and the kicker would have acted the same even if punitive damages were assessed against him. A fortiori, the award of fifty percent damages would leave everyone's behavior unchanged.

Consider Popov in this light. One might argue that the possibility of catching the record-breaking ball could have had an effect on the decision of fans to attend the game or to sit in a certain part of the stadium. But this misses the mark. The relevant inquiry is not whether Popov's or Hayashi's ex ante decision to attend the game was influenced by the possibility of acquiring sole ownership of the ball. Rather, the key question is whether, given the intractable nature of the dispute between them, either party would have altered his ex ante behavior if a compromise remedy were substituted for a fifty-fifty chance at an exclusive remedy. Thus stated, it becomes apparent that the only difference between the two remedies turns on the parties' risk aversion. ${ }^{33}$

32 As it concerns the actual facts of Vosburg, this statement should be qualified by a more careful appraisal of the historical record, which reveals that the plaintiff's leg had been previously injured and that both victim and kicker may have known that it was fragile. Zile, supra note 16, at 880-81, 958. Presumably, however, nobody thought it was remotely likely that a slight touch could produce such dire consequences. But whether either party was behaving reasonably by failing to take precautions turns out to be a somewhat more problematic question than is typically assumed.

33 In order to arrive at the outcome in this case, one needs to travel down a decision tree whose nodes include attending the game, the home run being hit, catching the ball, and becoming involved in an ownership dispute that may be resolved either way with equal probability. If both parties were risk neutral, they would be indifferent between the two remedies. Of course, if both were risk seeking, they would prefer an all-or-nothing remedy, but risk-seeking parties seem implausible. If both were risk averse, they would favor the split-the-difference remedy. The differences in utility between these two legal 


\begin{tabular}{|c|c|c|c|}
\hline 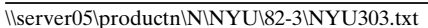 & unknown & Seq: 10 & 8-MAY-07 \\
\hline
\end{tabular}

We begin the remainder of this Article with a brief discussion of the intellectual history of the split-the-difference remedy. Several scholars have addressed the possibility of a split-the-difference remedy, but our analysis offers several original and valuable insights. One of our key insights is that windfall cases form the appropriate domain for split-the-difference cases. It is therefore incumbent on us to offer a clear and operable definition of what constitutes a windfall, which we do in Part II. Part III demonstrates why risk aversion, fairness, and doctrinal integrity favor a splitting remedy in windfall cases. Part IV explains how a split-the-difference remedy could be applied to several areas of contract law that already screen for windfalls as well as to other common law areas. In Part V, we take on several objections to splitting and show why they are largely without merit in the context of windfall cases.

\section{I \\ INTELLECTUAL History}

We are certainly not the first to consider the idea of compromise remedies. The idea can be traced into the distant past. For example, Jewish law provides the following:

If two laid hold of a cloak [a talit, or prayer shawl] and one said, ... 'The whole of it is mine', and the other said, 'The whole of it is mine', each must take an oath that he claims not less than the half of it and they divide it between them. If one said, 'The whole of it is mine', and the other said, 'The half of it is mine', he that [claimed the whole] must take an oath that he claims not less than threequarters, and he that [claimed half] must take an oath that he claims not less than one quarter; and the former takes three-quarters and the latter one-quarter. ${ }^{34}$

Joseph Jaconelli discovered a brief reference to the problem in Hume's A Treatise of Human Nature, in which the philosopher made the following observation:

[T]ho' abstract reasoning, and the general maxims of philosophy and law establish this position, that property, and right, and obligation admit not of degrees, yet in our common and negligent way of thinking, we find great difficulty to entertain that opinion, and do even secretly embrace the contrary principle.... ["Referees"] commonly discover so much equity and justice on both sides, as induces them to strike a medium, and divide the difference betwixt the par-

rules, when multiplied by the vanishingly small probability of becoming involved in a dispute of the kind just described, should have no effect on any ex ante behavior such as the decision to attend a game.

34 The Mishnah 347 (Herbert Danby trans., Oxford Univ. Press 1933). 


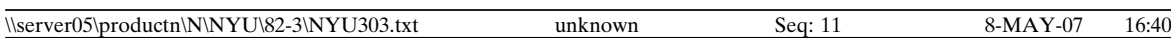

ties. Civil judges, who have not this liberty, but are oblig'd to give a decisive sentence on some one side, are often at a loss how to determine, and are necessitated to proceed on the most frivolous reasons in the world. Half rights and obligations, which seem so natural in common life, are perfect absurdities in their tribunal; for which reason they are often oblig'd to take half arguments for whole ones, in order to terminate the affair one way or other. ${ }^{35}$

A number of scholars have hinted more recently at a split-thedifference remedy, and some seem to advocate splitting in circumstances similar to those we define as windfalls. One such suggestion was offered by Warren Seavey, who wrote that in unjust enrichment cases:

unless there is more than a purely technical reason for preferring one of the [parties] rather than the other, it would seem just that they should share losses equally. But . . . the courts have thus far resisted, or more properly, ignored, my blandishments as well as the maxim of equity about equality. ${ }^{36}$

From his discussion of the cases, Seavey seems to have in mind something roughly like our windfall principle as the basis for a split-thedifference remedy, at least as applied to unjust enrichment cases, although he never articulates it as a general rule.

Philip Weiss also advanced an equity-based rationale for splitting in certain cases of contractual disputes:

Because the occasion for discharge [in these cases] is ordinarily an externally caused, unknown, or unanticipated event [i.e., a windfall], neither party will have assumed the risk in the vast majority of cases and neither party will be a "wrongdoer" to whom the court can easily assign responsibility for loss. Thus, only innocent parties will bear losses resulting from a contract discharged as burdensome, and therefore equitable considerations ... suggest that ... losses should not be sustained by one party, but should be evenly shared. ${ }^{37}$

More recently, William Young noted that the Restatement (Second) of Contracts afforded judges increasing scope for compromise remedies-what he termed "Half Measures"-by incorporating language about "avoiding injustice" into sections dealing with mistake, impracticability, and remedies generally. ${ }^{38}$ Young's primary

353 David Hume, A Treatise of Human Nature 530-31 (L.A. Selby-Bigge ed., London, Oxford Univ. Press 1888), quoted in Joseph Jaconelli, Solomonic Justice and the Common Law, 12 Oxford J. Legal Stud. 480, 481 (1992) (noting Hume's Treatise as rare in observing absence of compromise judgment from common law).

36 Warren A. Seavey, Problems in Restitution, 7 OKLA. L. Rev. 257, 274 (1954).

37 Philip D. Weiss, Apportioning Loss After Discharge of a Burdensome Contract: A Statutory Solution, 69 YALE L.J. 1054, 1058-59 (1960).

38 W.F. Young, Half Measures, 81 Colum. L. Rev. 19, 19 (1981). 
concern was descriptive rather than normative or analytic. He did not take a strong position on the desirability of awarding a prevailing plaintiff something less than expectation damages, but merely noted that the Restatement could be read as authorizing courts to do so and pointed out that courts were occasionally making use of that authority. ${ }^{39}$ He concluded by noting that little "theory supports the justice-based relief under Restatement provisions. These provisions are curiously like narrow holdings in common law cases: they are authority for principles, but what principles they establish is for the future to say." 40

Grant Gilmore suggested in passing that a kind of loss-sharing might be appropriate in at least a limited set of contractual circumstances that sound similar to those we characterize as windfalls. ${ }^{41}$ Charles Fried's more extensive analysis also concluded that there is a class of "contractual accidents" for which loss-sharing is a good remedy. ${ }^{42}$ Fried characterized mistake, frustration, impossibility, and found property cases as situations in which

there may be no basis for holding the parties responsible or accountable to one another. Rather, persons in some relation, perhaps engaged in some common enterprise, suffer an unexpected loss or receive an unexpected gain. The sharing principle comes into play where no agreement obtains, no one in the relationship is at fault, and no one has conferred a benefit. Sharing applies where

39 Id. passim.

$40 I d$. at 36. Several others have also suggested the possibility of splitting or compromise in these areas, usually on fairness grounds. See, e.g., Jeffrey L. Harrison, A Case for Loss Sharing, 56 S. CAL. L. REv. 573, 575 (1983) (characterizing contracts as type of "moral partnership" or "common enterprise," so associated reliance losses should be treated analogously to unanticipated partnership losses).

41 See Grant Gilmore, The Death of Contract 77-78 (1974) (discussing preinsurance cases of absolute liability). Gilmore discusses with apparent approval a set of cases in which there was a contract to build a structure that,

having been almost completed, was blown down or burnt down or sank into the mud-all without any fault being attributable to the builder.... [When the owner sued the builder, the court gave] judgment for [the] plaintiff-owner [on the theory that] the builder is not excused from the duty voluntarily assumed even by accident or inevitable necessity .... The apparent meaning of the cases is that the unhappy builder must go on building, no matter how many times the structure collapses, all for the originally agreed contract price-or pay damages for not doing so. On closer examination, however, it turns out that all that was involved in the cases was the recovery of downpayments or progress payments made by the owner in the course of construction-a result which might be described as a form of loss-sharing.

Id. at 78 .

42 Charles Fried, Contract as Promise 70-71 (1981). We are grateful to Michael Fischl for both the Fried and Gilmore references. 


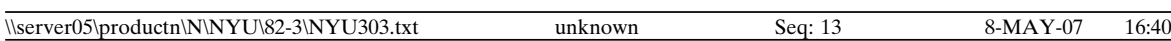

there are no rights to respect. . . . It is particularly appropriate to . . p picking up after contractual accidents. ${ }^{43}$

These situations sound much like our definition of windfalls.

Richard Helmholz advocated splitting for cases governing the division of found property, ${ }^{44}$ drawing explicitly on a 1939 Comment in the Fordham Law Review that was the first to see found property as an appropriate locus for splitting. ${ }^{45}$ Helmholz argued, largely atheoretically, that the cases are wildly inconsistent and at odds with each other, and that the reason for this incoherence is that the distinctions that ostensibly drive the judges' preference for either the site owner's or the finder's claim are unworkable and too "fine." 46 That led him to see splitting as a preferable alternative.

John Coons's pioneering article Approaches to Court Imposed Compromise-the Uses of Doubt and Reason began the systematic analysis of compromise remedies. ${ }^{47}$ Coons situated the problem of compromise in the familiar tension between law's commitment to abstract rules on the one hand and to doing justice in individual cases on the other. He pointed out that although common law jurisprudence almost never permits a court to award anything other than a winner-take-all remedy, ${ }^{48}$ there are nevertheless times when an all-ornothing result is at odds with our sense of justice. He offered a partial list of such circumstances (including the good-faith purchaser cases we discuss above), ${ }^{49}$ and a taxonomy of reasons for splitting. Broadly speaking, he identified two classes of rationales for splitting: those based on "doubt" (uncertainty about which party should win, given the evidence), and those based on "reason" (such as the substantive fairness of a split outcome). ${ }^{50}$

\footnotetext{
43 Id.

44 R.H. Helmholz, Equitable Division and the Law of Finders, 52 Fordham L. Rev. 313 (1983).

45 Comment, Lost, Mislaid, and Abandoned Property, 8 Fordham L. Rev. 222, 237 (1939).

46 Helmholz, supra note 44, at 315, 317-21.

47 John E. Coons, Approaches to Court Imposed Compromise-the Uses of Doubt and Reason, 58 Nw. U. L. Rev. 750 (1964). The article was the occasion for a symposium attended by some of the greatest scholars of jurisprudence of the era, including Paul Freund and Lon Fuller; some of their oral comments accompany the Coons article and are well worth reading. See generally Francis A. Allen et al., Comments on Approaches to Court Imposed Compromise-the Uses of Doubt and Reason, 58 Nw. U. L. Rev. 795 (1964).

48 See Coons, supra note 47, at 767, 776 n.19 (noting scattered exceptions to winnertake-all remedy, such as general average principle in admiralty law).

49 See supra note 25 and accompanying text.

50 Coons, supra note 47 , at 754-73 (doubt); id. at 773-79 (reason).
} 
These reasons notwithstanding, Coons articulated the case for compromise remedies only in a limited set of cases. ${ }^{51}$ He noted that although compromise is most compelling when the legal rules give each side an equal probability of prevailing, this equality is not exogenous or environmentally "given." 52 Rather, it depends on "antecedent judgment[s] by the trier of fact" and is thus not a natural or political equality that constitutes a universal first principle. ${ }^{53}$ This in turn suggests - as we independently concluded - that the relaxation of the winner-take-all principle could create adverse incentives for fact finders. ${ }^{54}$

Since the early 1980s, several scholars have advanced what Coons would call the doubt-based rationale for splitting, or splitting because of indeterminacy in fact-finding. Many of these works explore the possibility of replacing the preponderance-of-the-evidence rule with a more fine-tuned, probabilistic approach that would not require a winner-take-all outcome. ${ }^{55}$ The most recent and most ambitious con-

51 See id. at 788 (noting objections to splitting and that they are minimized in circumstances where "compromise is effected through non-discretionary rules based upon a rationale either of indeterminacy or policy"); see also id. at 763-64 (articulating circumstances in which splitting based on doubt is appropriate); $i d$. at 774-75 (articulating circumstances in which splitting based on policy or "sufficiency of reason" is appropriate).

52 Id. at 760.

53 Id.

54 Abandonment of the winner-take-all rule, Coons suggests, could lead to [t]emptations to the trier of fact .... The problem would appear particularly acute in jury trials where the possibility of compromise would tend to erode the incentive for careful argument of strongly held opinions. If winner take all had no other virtue it does demand an effort from the jury at a healthy clarity of judgment.

Id. at 761; see also Jaconelli, supra note 35, at 496-506 (exploring Coonsian themes and suggesting that winner-take-all principle emerges from law's grounding in practical concerns that temper its aspirations to do justice).

Coons suggests that judges would be less subject to such temptations. This is not a problem of workload per se, since the judge still has to hear all the evidence and decide each case. The problem is that the burden of proof and winner-take-all mechanism "protect [judges] from a species of embarrassment that lurks in every hard case. Resolving factual issues against good men is often a distasteful duty. Remove that duty in close cases, and it is likely that more and more cases will begin to seem close." Coons, supra note 47, at 762. We suggest in Part V.A, however, that by limiting the scope of compromise remedies to windfall cases we avoid most, if not all, of the problems Coons identified. Moreover, as we argue below, there are countervailing tendencies that Coons did not see and which, we claim, are sufficient to overcome these objections.

55 For example, David Rosenberg argued that in mass exposure tort cases, such as those involving diethylstilbestrol (DES) and asbestos, the preponderance-of-the-evidence rule makes it virtually impossible for plaintiffs to prove that a particular manufacturer is liable for the harm they suffered. Thus, Rosenberg proposed that the preponderance-ofthe-evidence rule be replaced in such cases with a standard of proportional liability that does not depend on individualized proof of a causal connection. David Rosenberg, The Causal Connection in Mass Exposure Cases: A "Public Law" Vision of the Tort System, 97 


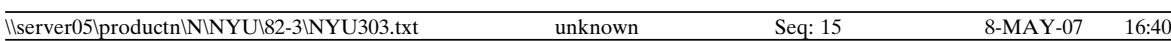

tribution to this thread of scholarship was made by Michael Abramowicz. Abramowicz advanced the idea of a two-tier verdict system: If the fact finder's confidence in the defendant's liability (or lack thereof) exceeds a certain threshold, it would adopt an all-ornothing verdict; if, by contrast, the fact finder's confidence falls below that threshold, it would adopt a compromise award. ${ }^{56}$

While fascinating, this discussion lies beyond the scope of our paper. We focus on cases in which law should affirmatively prescribe equal sharing of an entitlement not out of uncertainty about the correct outcome, but because splitting is substantively correct. Our goal is to identify the circumstances under which it is desirable to split an entitlement between the claimants even when the court is in possession of all relevant evidence.

Consider again the Popov case. In that instance, the whole incident was captured on videotape. Thus, the judge could easily have decided who had first possession of the baseball and awarded it to that party. The judge's decision to auction off the ball instead and split the proceeds between the parties was, therefore, not grounded in evidentiary doubt but rather in the belief that it was the right thing to do substantively. More generally, the focal point of our analysis is not the epistemological justifications for splitting but the ontological ones.

Although we share a starting point with Coons, we reach different conclusions. At the end of the day, Coons was skeptical about split-the-difference remedies, but we propose and defend workable nondiscretionary rules for identifying cases where split-the-difference remedies are to be applied. Moreover, we suggest that Coons's fear that the introduction of compromise remedies would result in high judicial-error costs is ill-founded.

Harv. L. Rev. 849, 858-59 (1984); see also John Makdisi, Proportional Liability: A Comprehensive Rule to Apportion Tort Damages Based on Probability, 67 N.C. L. Rev. 1063, 1067-75 (1989) (stating problem in more general terms and advocating proportional liability in tort cases universally); Steven Shavell, Uncertainty over Causation and the Determination of Civil Liability, 28 J.L. \& ECON. 587, 589, 597-98, 604 (1985) (suggesting that proportional liability can help achieve optimal deterrence, albeit at expense of higher litigation costs). In contrast, Charles Nesson cautioned against the broad adoption of proportional liability. His main concern was that proportional liability based on a company's market share would undermine "the basic negligence rule and its behavioral norm." Charles Nesson, The Evidence or the Event? On Judicial Proof and the Acceptability of Verdicts, 98 HARv. L. REv. 1357, 1383 (1985). Coons made a similar point, relying loosely on psychoanalytic theory: Splitting is soft and maternal while all-or-nothing rules are strict and unyielding, traditionally male traits that he saw as supporting respect for the law. Coons, supra note 47, at 771.

56 Michael Abramowicz, A Compromise Approach to Compromise Verdicts, 89 CAL. L. REV. 231, 237 (2001). 


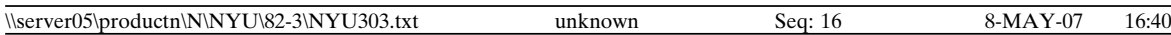

First, we show that there is a compelling principle-the idea of windfalls - that limits the applicability of compromise remedies to those cases where neither party could reasonably do anything to anticipate, prevent, or allocate the risk of the problem ex ante. Restricting the applicability of compromise to windfall cases automatically limits the scope of judicial discretion because the power to split would require a finding of a windfall. Moreover, for reasons we explain in Part V.C, once a windfall is found, we would permit only a fifty-fifty split, further limiting discretion.

Second, while much previous discussion of compromise remedies has been theoretically motivated, relatively little of it has been grounded in actual doctrine. Our analysis is. For example, we demonstrate how certain contract doctrines screen for just those situations in which windfalls are most likely to occur and in which a fifty-fifty split is therefore justified. We identify other doctrinal areas with similar characteristics as well.

Finally, we answer the judicial incentives problem with a novel insight. Suppose it is true that the availability of compromise remedies does have some adverse effect on judicial behavior by encouraging judges to compromise rather than work harder to discover which party should really win. Counterintuitively, we show that the introduction of a split-the-difference option may nevertheless improve the accuracy of judicial decisionmaking, as compared to a common law no-splitting world, given that judges already get some decisions wrong. This is so because the cases in which judges would be most tempted to adopt a split verdict under our system are precisely the cases that would be most likely to be incorrectly decided under the status quo. Making a small mistake (splitting) is better than making a large one (a full verdict for the wrong party).

\section{II}

\section{DeFining WindFAlls}

We have two goals in this Part. First, we introduce and explain common situations that create a windfall gain or loss. Despite the fact that the term "windfall" usually connotes an unexpected positive payoff (and most legal scholars treat it as such), ${ }^{57}$ we will show that the reverse possibility of an unexpected negative payoff raises a similar set of concerns, and that both types should be treated symmetrically. Second, we offer our own definition of windfalls.

\footnotetext{
57 See, e.g., Kades, supra note 31, at 1491 ("In common usage, a windfall is a 'casual or unexpected acquisition or advantage,' or an 'unexpectedly large or unforeseen profit.'” (quoting 20 Oxford English Dictionary 378 (2d ed. 1989))).
} 


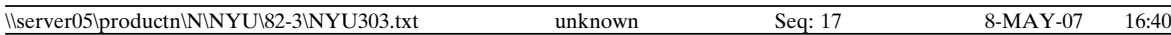

\section{A. The Windfall Problem}

The cases of interest to us are those in which unforeseeable circumstances result in a loss or gain for one or the other of two interacting parties. This set of cases is often said to involve "windfalls." Historically, the term "windfalls" originated in the rule that farmers were prohibited from chopping down trees in Crown forests for firewood but were entitled to collect branches that fell off as a result of strong gusts. ${ }^{58}$ In modern times, the term has taken on a broader meaning of unexpected good fortune. ${ }^{59}$ In an excellent article on the subject, Eric Kades defined "windfalls" for purposes of legal analysis as "economic gains independent of work, planning, or other productive activities that society wishes to reward."60 Kades's definition, however, is not quite right for our purposes.

58 Id. (quoting William Morris \& Mary Morris, Morris Dictionary of Word And Phrase Origins 605 (1977)).

59 Id.

$60 I d$. Kades's project, however, is very different from ours. Kades's goal was to establish an analytic and legal framework for taxing windfalls. Consequently, Kades focused on positive windfalls that create surplus for the recipients but not on negative windfalls that inflict an unanticipated loss. Thus, an unforeseeable hike in oil prices which raises the profits on already-discovered oil falls under Kades's definition of a windfall, but a loss resulting from the cancellation of a coronation does not.

The reason for Kades's disparate treatment of positive and negative windfalls is his belief that negative windfalls should be addressed through private insurance. Id. at 1497-98. However, there are a few related problems with insurance as an adequate response to negative windfalls. First, actors who suffer a loss as a result of a negative windfall often do not have insurance. Moreover, one cannot blame the actor for not buying "negative windfall" insurance both because windfalls, by definition, are unforeseeable, and because such an insurance mechanism is often not available, as exemplified by the Coronation Cases. See infra notes 114-18 and accompanying text (discussing Coronation Cases). Finally, given the problems of moral hazard and adverse selection that plague insurance markets, insurance may sometimes be unavailable even to a party who wishes to purchase it. Therefore, we claim that a more appropriate definition of windfalls should include losses as well as gains, and that a policy that focuses only on gains misses an important set of cases.

Another important difference between this Article and Kades's is that his orientation is toward public windfalls, Kades, supra note 31, at 1493, an orientation that follows naturally from his focus on redistributing windfalls through tax policy. In this spirit, therefore, Kades refers to "private windfalls" as "[r]arely [w]indfalls, [n]ever [w]orth [c]apture." Id. at 1504. Private windfalls, however, are the focus of our inquiry. Furthermore, while Kades's concern is "capture" by the state and (re)distribution to society at large, id. at 1493-94, ours is to operationalize a mechanism to redistribute gains and losses as between the parties to the dispute. Accordingly, we do not focus on a tax-oriented solution but rather on the more workable framework of common law remedies and rules of decision. The primary virtue of our solution is that it is cheaper to administer and is thus capable of addressing a much wider range of circumstances. Moreover, as Kades acknowledged, a tax on windfalls raises a concern that policymakers would be too eager to find windfalls and tax them even when none existed. Id. at 1505-10. Our proposal, by contrast, avoids this concern: Judges should have no inherent incentive to favor one party over another, and so abuse of discretion should be minimal. 


\begin{tabular}{|c|c|c|c|}
\hline 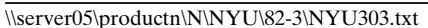 & unknown & Seq: 18 & 8-MAY-07 \\
\hline
\end{tabular}

\section{B. Defining Windfalls}

Most windfalls are not literally unforeseeable. As Calamari and Perillo wryly note, "[a]nyone who has read a bit of history can foresee, in a general way, the possibility of war, revolution, embargo, plague, terrorism, ... or the recurrence of an ice age, among other horrors." 61 Calamari and Perillo suggest that an event should be considered legally unforeseeable if it is "so unlikely to occur that reasonable parties see no need explicitly to allocate the risk of its occurrence, although the impact it might have would be of such magnitude that the parties would have negotiated over it, had the event been more likely." 62

Expanding on this insight outside of a contractual setting, we define a windfall as an event whose expected value is substantially smaller than the costs of any action to prevent or contract for it. The expected value of some event to party $I$ is $I$ 's subjective probability that the event will occur multiplied by the subjective magnitude of the event (the estimated dollar cost or benefit). ${ }^{63}$ Events that are exceedingly unlikely — such as a meteorite crashing into one's house-have a small expected value: Although the meteorite would presumably inflict considerable damage if it were to hit, the probability of such an occurrence is so small that one would expect to live several thousand lifetimes in order to experience one such event.64 Of course, events that are very probable but of a very small magnitude-for example, a mosquito crashing into one's house-also have small expected values. ${ }^{65}$

61 Joseph M. Perillo, Calamari \& Perillo on Contracts 547-48 (5th ed. 2003).

62 Id. at 548. Calamari and Perillo credit Pietro Trimarchi, Commercial Impracticability in Contract Law: An Economic Analysis, 11 Int. Rev. L. \& Econ. 63, 65 n.9 (1991), for this formulation.

63 Hence, $E_{i}(X)=p_{i} \times m_{i}$, where $E$ is the expected value function, $p_{i}$ is the subjective probability, and $m_{i}$ is the subjective magnitude of the event.

64 "How likely is a meteor to smash into your house? Less than 1 in 182 trillion [in your lifetime]," according to one source. Margo Harakas, Odd Odds: What Are the Chances That You . . . , Sun-SEntinel (Fort Lauderdale, Fla.), Jan. 24, 2002, at 1E. Of course, one might question the actuarial basis for this calculation, which was not given. A search of the Lexis major newspapers database revealed that at least three meteorites crashed into houses in the United States in 2003. See Kate N. Grossman, Meteorites CrashLand in Suburbs; Rare Showers Put Holes in Roofs, Draw Eager Observers, CHI. SunTimes, Mar. 28, 2003, at 18 (describing two houses hit by meteorites); Kevin O'Neal, Rock That Struck Insulation Is a Hot Topic, Indianapolis STAR, Dec. 10, 2003, at B3 (reporting apparent meteorite strike on construction materials near house). Given a total of roughly one hundred million housing units in the United States, if we take 2003 as typical and assume three strikes per year, the odds look something like one in thirty-three million. In any event, the probability of a meteorite strike is clearly very small.

65 One court defined the problem similarly, suggesting that one should look 


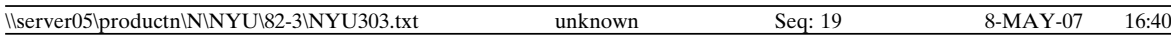

It is not sufficient that some event has a small expected value: A windfall exists only if the expected value of some contingency is small relative to the costs of doing something about the contingency. ${ }^{66} \mathrm{We}$ are deliberately vague here because "doing something" is meant to cover at least two activities. An obvious action one might take in the face of some future risk is to implement precautions designed to reduce its likelihood or severity. For example, in Vosburg, the defendant could have refrained from kicking the plaintiff or worn softer shoes; likewise, the plaintiff could have kept his distance from other children or worn knee padding. ${ }^{67}$ Even when precautions against a risk are unavailable or simply not worthwhile, parties can sometimes resort to a second response: They can contract ex ante to allocate a possible windfall. For example, in Sherwood, the buyer and seller could have addressed in their sale agreement what would happen if the cow turned out to be fertile. Their failure to do so strongly suggests that they considered the cow's infertility to be a settled matter and the fertility risk not worth worrying about.

In sum, there are several elements that define windfalls for our purposes and one important consequence that flows from our definition. By our definition, a windfall exists if the expected value of some contingency is small relative to the costs of doing something about the contingency, and if the magnitude of the contingency is large enough that the parties would do something about it were its occurrence more likely. Additionally, a windfall exists only if the parties are equally situated with respect to the windfall ex ante ${ }^{68}$ - so if the contingency was only unforeseeable to one party, or if the risk of the contingency

first [at] how likely the occurrence of the event in question was and, second whether its occurrence, based on past experience, was of such reasonable likelihood that the obligor should not merely foresee the risk but, because of the degree of its likelihood, the obligor should have guarded against it or provided for non-liability against the risk.

Opera Co. of Boston v. Wolf Trap Found., 817 F.2d 1094, 1103 (4th Cir. 1987).

66 Note the similarity to Learned Hand's famous formula in torts. See United States v. Carroll Towing, 159 F.2d 169, 173 (2d Cir. 1947) (defining negligence as failure to take precaution that is cost-justified, meaning that expected savings-reduction in probability of harm multiplied by magnitude of accident—are less than cost of precaution); see also Basic Inc. v. Levinson, 485 U.S. 224, 238 (1988) (defining materiality as depending on probability that event will occur and anticipated magnitude of event).

67 Parties may also be able to invest in learning about the probability of a windfall. For example, the plaintiff in Vosberg might have been able to get a medical examination to diagnose his condition. But of course, the decision about whether to get such an examination is subject to the same kind of cost-benefit calculation as the decision about precautions-it hardly makes sense to pay any significant amount to be tested for a medical condition if you believe you have a one-in-a-million chance of suffering from it.

68 See infra text accompanying notes 87-88 (discussing arbitrariness of ex ante possession in mistake and impossibility cases). 
can be otherwise properly allocated to one party, no windfall exists. ${ }^{69}$ Finally, there is one important consequence of our definition that is worth emphasizing here, as it is important to our normative justification for splitting windfalls: Because the cost of doing something about the contingency is greater than its expected value, a change in how windfalls are allocated will not alter the ex ante behavior of either party. ${ }^{70}$ By our definition, then, a change in the rule for how windfalls are allocated would not change the total number of windfalls created, nor would it induce parties to allocate the risk of windfalls ex ante.

III

The Normative Case for a Split-the-Difference Remedy

Having defined what constitutes a windfall, our solution to private windfall cases is startlingly simple: Once a windfall is identified, we propose that courts split the gain or loss evenly between the plaintiff and the defendant. In this Part, we present a normative justification for this rule. We show that in appropriate cases a split-thedifference remedy is both efficient and fair. We explain in Part IV how splitting provides doctrinal integrity.

\section{A. Efficiency: Splitting the Difference Provides Valuable Insurance}

Consider the two participants in Popov, Messrs. Hayashi and Popov. If we assume that both of them are risk averse, it will necessarily be true that uncertainty about the outcome of the trial will be harmful to each. ${ }^{71}$ Put another way, each would prefer to have a certain gain of $\$ 500,000$ rather than to go to trial with a fifty percent

69 Hadley v. Baxendale, (1854) 156 Eng. Rep. 145 (Exch. Div.), provides an example of an event that would not constitute a windfall by our definition because it was unforeseeable to only one party. In Hadley, the plaintiff shipped his mill's broken shaft for repair using the defendant as its carrier. When the shaft was delayed, the plaintiff attempted to collect for the profits lost when his mill remained closed. The court famously held that unforeseeable consequential damages were not recoverable. Id. at 151. In Hadley, the lack of a replacement shaft that kept the mill closed was (arguably) not foreseeable to the defendant shipper, but was of course known to the plaintiff mill owner. In windfall cases, by contrast, nobody has any private information, and the event (such as the fertility of the cow in Sherwood) is not foreseeable to either party.

70 This is true because, by our definition, the cost of doing anything to prevent or allocate the windfall ex ante is greater than the expected value of the entire windfall. If a party expects to receive less than the full value of the windfall, then the expected value of the windfall to that party is reduced while the cost of preventing or allocating the windfall remains the same, so a change in ex ante behavior becomes even less cost justified.

71 Abramowicz, supra note 56, at 239-40 (making same point). 
chance of winning sole custody of the $\$ 1,000,000$ ball and a fifty percent chance of winning nothing. ${ }^{72}$

With some crude assumptions, it is even possible to quantifyalbeit in a rough way-how much the parties would gain from splitting the ball rather than going to trial and risking a judgment that would award it to one or the other. Table 1 gives these calculations. Start by assuming that both parties had lifetime wealth of $\$ 1.2$ million in present value. ${ }^{73}$ The ball in dispute was expected to sell for about $\$ 1$ million, eighty percent more than either fan's pretrial wealth. We assume a simple utility function of the form $U($ Wealth $)=\ln ($ Wealth $) .{ }^{74}$

Given this relationship between wealth and utility, we can compute each party's expected utility from a gamble in which the ownership of the ball is determined at trial with each fan having a fifty percent chance of prevailing. ${ }^{75}$ The expected utility of going to trial is

$$
E\left(U_{\text {trial }}\right)=0.5 \ln (\text { Wealth if Win })+0.5 \ln (\text { Wealth if Lose })
$$

which-given the assumptions in Table 1-translates to 14.30 Utils. Now we need to ask, what amount of wealth, if held with certainty, would provide this same amount of utility? The answer is $\$ 1,624,808 .^{76}$ That means that given each party's risk aversion and existing wealth, each would be just as happy with a certain gain of $\$ 1,624,808$ as with going to trial, a gamble that has a fifty percent chance of yielding $\$ 1.2$ million (no gain) and a fifty percent chance of yielding $\$ 2.2$ million (a $\$ 1$ million gain).

In fact, however, the parties could do better than this: By splitting the ball's value, each assures himself of $\$ 500,000$ for a guaranteed total wealth of $\$ 1.7$ million. The difference between the outcome under splitting and the certainty equivalent of the outcome at trial-

72 Although the Popov ball only sold for about $\$ 400,000$, the opinion notes that it was expected to sell for "something in excess of $\$ 1,000,000$ " at the time the decision was handed down. Popov v. Hayashi, No. 400545, 2002 WL 31833731, at*1 n.1 (Cal. Super. Ct. Dec. 18, 2002).

73 This is a rough estimate of the present value of someone's lifetime income, assuming current net earnings of $\$ 30,000$ per year, a remaining working career of forty years, a future earnings growth rate of three percent per year, and a discount rate of three percent per year.

74 Logarithmic utility is the limit of $W^{1-r} /(1-r)$ as $r$ approaches 1, where $r$ is the coefficient of risk aversion and the function exhibits the property of constant relative risk aversion. See generally Christian Gollier, The Economics of Risk and Time 27-31 (2001).

75 It seems plausible to assume that the probability of winning was fifty percent for each since the judge decided-in the end-that he could not determine who had the stronger case. Popov, 2002 WL 31833731, at $* 8$. Both sides made arguments for why they deserved to be awarded title of the ball, but in predicting the judge's decision, both should have realized that the outcome was essentially a coin flip.

76 We want $W$ such that $\ln (W)=14.30$, so $W=\exp (14.30)=\$ 1,624,808$. 
just under $\$ 75,200^{77}$-represents the insurance gain from splitting ex ante rather than assuming the risk. ${ }^{78}$

Table 1: One-Party Welfare Gain from Splitting in Popov

\begin{tabular}{|l|l|}
\hline Annual Income & $\$ 30,000$ \\
\hline Life Expectancy in Years & 40 \\
\hline NPV Lifetime Wealth* & $\$ 1,200,000$ \\
\hline & \\
\hline Anticipated Value of Ball When Sold & $\$ 1,000,000$ \\
\hline Utility Function & $U(W)=\ln (W)$ \\
\hline Probability of Plaintiff Win at Trial & 0.5 \\
\hline Expected Utility of Going to Trial & 14.301 \\
\hline a. Certainty Equivalent & $\$ 1,624,808$ \\
\hline & 14.346 \\
\hline Utility Of 1/2 Ball For Sure & $\$ 1,700,000$ \\
\hline b. "Certainty Equivalent" & \\
\hline & $\$ 75,192$ \\
\hline Net Dollar Gain from Splitting (b) - (a) & \\
\hline
\end{tabular}

* Assumes that growth rate of income and discount rate are the same.

The regime we propose will impose some administrative costs on courts. ${ }^{79}$ However, the administrative costs of our proposal should be

77 The exact amount of this gain will depend on how risk averse the party actually is, but so long as $r>1$, the difference will always be positive. In other words, so long as the party is somewhat risk averse, there will always be an insurance gain. The total social gain, of course, includes both parties' gains; if they are both precisely as risk averse as we have assumed, then the total gain would be $\$ 150,400$ (twice $\$ 75,200$ ).

78 If the parties are indeed risk averse, one might ask why they did not obtain these insurance gains themselves by settling the suit instead of having the court "impose" a settlement on them. Of course, most cases do settle, both because of risk aversion and in order to save litigation costs. Our concern is with the small minority of cases that end up going to trial, perhaps because the parties have different (overly optimistic) assessments of their own likelihood of prevailing at trial. This does not contradict our assumption of risk aversion because the parties' unwillingness to settle is dictated not by their appetite for risk but rather by their (mis)perceptions of the actual risk of going to trial.

79 Andrew Kull has argued that in light of the administrative expense of reallocating windfalls and the difficulty of doing so in a manner that is more efficient or fair, courts do and should leave them where they lie in mistake and frustration cases. Kull, supra note 31 at 6-8. To the extent that his article is descriptive of what courts do in these cases, it is beyond the scope of our inquiry, although we note that he critiques numerous arguments that favor courts intervening in windfalls. Id. at 38-54. In the course of his argument in favor of judicial passivity, Kull clearly explains why neither party to a contract deserves the windfall more than the other, $i d$. at $42-54$, and we of course agree with him on that. Kull also notes that "[i]ntuitive standards of 'fairness' may suggest that a loss be borne . . . by the many rather than the few; by both parties to the contract rather than one alone." $I d$. at 
small. Since contract law creates defenses in certain windfall situations, ${ }^{80}$ courts already must determine whether a windfall is present. ${ }^{81}$ A split-the-difference remedy adds only the additional step of valuing the windfall and dividing it evenly between the parties. Not only will these costs be small, but they are not likely to be greater than the costs of the current regime. Courts are not blind to the unfairness of windfalls and employ (or consider employing) numerous approaches to correcting them. These approaches entail considerable expense, whereas ours has the virtue of requiring only identifying the windfall and dividing it in two. ${ }^{82}$ Even leaving windfalls where they fall imposes costs. Leaving a windfall with the party who possesses it at the time it is discovered invites parties to waste resources jockeying for possession, and parties may be unwilling to trust each other with possession even when it would otherwise be worthwhile to do so.

While we reject a policy of judicial apathy, we do agree that courts should be cautious when asked to award a split-the-difference remedy against a party who has discovered a windfall, lest courts reduce the incentive of such parties to maximize the value of what they have acquired. ${ }^{83}$ In considering the ex ante effects of compromise remedies, courts must consider the impact of their decision on all actions, not just those preceding performance. ${ }^{84}$

42. Kull does not make much of this intuition, which we of course share. Instead, he addresses commentators who would place windfalls on superior risk bearers. We take no position on that argument but instead propose compromise remedies for when no one is a superior risk bearer.

80 See infra Part IV.

81 Even where the relevant doctrine does not screen for windfalls in the way that some contract doctrine does, see infra Part IV, identifying windfalls should be no more complicated than applying the Hand formula, see supra note 66, an exercise already familiar to courts from tort law.

82 Even this may overstate the cost of our regime. For example, in some cases, a court can avoid all costs of allocating the windfall by requiring the party asserting the defense of mistake to name a price at which the other party could choose either to buy or sell the windfall. See infra note 176 and accompanying text (discussing "take or pay" regime for splitting windfalls).

83 See Anthony T. Kronman, Mistake, Disclosure, Information, and the Law of Contracts, 7 J. Legal Stud. 1, 13-14 (1978) (discussing right of exclusive use as incentive mechanism for maximizing value of property rights).

84 By the same reasoning, we would not recommend splitting the loss when goods are destroyed by an unavoidable accident after the date of a contract for their sale but before their delivery. The loss may be a windfall, but rules allocating the risk to one party or the other already provide certainty for the parties and allow them to insure against loss more economically. See E. Allan Farnsworth, Contracts $§ 9.5$, at 622 n.15 (4th ed. 2004) (describing U.C.C. rules that collectively describe when risk of loss passes from seller to buyer). 


\section{B. Splitting the Difference is Fair}

Fairness is a difficult concept, since there are myriad conflicting theories about what it means. Our analysis of these windfall cases leads us to argue that fairness requires symmetric treatment of the parties, which naturally leads to a split of the windfall gain or loss between them. In cases where nobody has a superior claim to the positive or negative windfall, it is almost tautological that the fair outcome is to divide the windfall evenly between the contesting parties. We are not the first to notice this, and indeed, the literature on compromise remedies is replete with versions of this claim, which is usually thought to be the main reason for splitting. ${ }^{85}$ But we can go further: An even split replicates the hypothetical bargain (known as the Nash bargaining equilibrium) that the parties would be predicted to strike beforehand if they were to negotiate over the windfall, know each other's preferences and opportunities, and each receive nothing in the absence of an agreement. ${ }^{86}$ Putting the parties in the position that they themselves would have agreed to under idealized conditions is the fairest way to deal with an unanticipated windfall.

To make things more concrete, suppose $A$ has an apple that she values at $\$ 0$ and $B$ has a banana that he values at $\$ 0$. $A$ values $B$ 's banana at $\$ 3$, whereas $B$ values $A$ 's apple at $\$ 2$. Each party knows the other's valuation. As things stand, the parties' total wealth is $\$ 0$. If they were to swap fruit, however, the parties' total wealth would increase to $\$ 5$, a gain of $\$ 5$ over the current situation. The Nash bargaining outcome is that this surplus of $\$ 5$ would be split evenly between the parties so that each gains $\$ 2.50$. This means that $A$ would give up her apple for the banana and pay $B$ an additional $\$ 0.50$. $A$ has a direct (gross) gain on the trade itself of $\$ 3$ less a payment of $\$ 0.50$ for a net of $\$ 2.50$; similarly, $B$ has a direct gain of $\$ 2$ plus an additional $\$ 0.50$ in payment from $A$ for a net of $\$ 2.50$. The Nash bargaining solution is thus a symmetrical division of the gains from trade. Since this model assumes rationality, common knowledge, no informational asymmetries, and many other requirements that may often not be met in the real world, it may not be a good guide to the results of actual

\footnotetext{
85 See supra Part I.

86 John F. Nash, Jr., The Bargaining Problem, 18 Econometrica 155 (1950). In particular, Nash models a potential bargain between "two individuals [who] are highly rational" and assumes that "each can accurately compare his desires for various things, that they are equal in bargaining skill, and that each has full knowledge of the tastes and preferences of the other." Id. at 155 . He further assumes that if the two parties fail to reach an agreement, each gets nothing. Id. at 157-58. Nash demonstrates that the equilibrium of this game is that each individual gets the same money profit from the bargain. Id. at 162. In other words, private bargaining (admittedly under restrictive assumptions) should result in a splitting of the surplus between the two bargainers.
} 
bargaining. However, it is precisely for this reason that a splitting rule is fair and matches our intuition that symmetrically situated parties should receive symmetrical results.

The existence of a true windfall-either positive or negativeleaves the parties symmetrically situated with respect to their normative entitlement to the gain or loss. By the definition of a windfall, neither party contributed any work, planning, or other productive activities (such as precautionary investment) to the achievement or prevention of the resulting gain or loss. Moreover, neither party had information that it should have used to effect a contractual allocation of the windfall given the costs of arranging such a provision. Hence, the parties are symmetrically situated.

Sherwood offers a clear example. The only reason that the plaintiff was the (frustrated) buyer rather than the seller was because the cow had not changed possession at the time that its pregnant status was discovered. Indeed, the arbitrariness of the parties' identities is a major theme of Andrew Kull's trenchant analysis of the mistake and impossibility cases. ${ }^{87}$ According to Kull, courts have no principled way of allocating the windfall in such cases, so they simply arrange things so as to leave ownership with the party who had possession at the time the windfall occurred. ${ }^{88}$ However, the fact that possession happens to reside with one or the other of the two parties seems udderly irrelevant to any justice-based claims about who should own the cow. Given that neither party has a compelling claim, splitting the increased value of the cow between the two parties best respects the inherent symmetry of their positions.

Something akin to our fairness rationale seems to have been operating in Popov. Judge McCarthy noted that the ball was jarred loose from Mr. Popov's grasp-before he had full control-by a crowd of people (which did not include the defendant, Mr. Hayashi). ${ }^{89}$ Neither party was at fault and, given the symmetry of the parties' positions, the opinion makes it quite clear that both had identical and equally valid claims to ownership. As Judge McCarthy put it, "Both men have a superior claim to the ball as against all the world. Each man has a claim of equal dignity as to the other. We are, therefore,

87 Kull, supra note 31 , at $41-42$.

$88 I d$. at 5-6. If the court wants to award ownership to the seller in possession, it finds mutual mistake and calls off the deal; if it wants to award ownership to the buyer in possession, it finds no mistake and affirms the deal.

89 Popov v. Hayashi, No. 400545, 2002 WL 31833731, at*1-2 (Cal. Super. Ct. Dec. 18, 2002). 


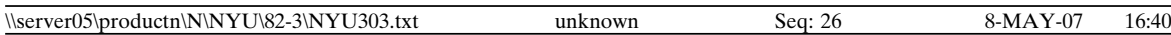

left with something of a dilemma. Thankfully, there is a middle ground." 90

The case for symmetry is somewhat more problematic in Vosburg where one party did (intentionally and wrongly) kick the other. While the kicker was obviously the agent for the ordinary and foreseeable loss resulting from his kick, it is much harder to argue that the resulting extraordinary and unforeseeable amputation was also his fault. Children do kick each other from time to time and if slight and gentle kicking is really wrong, almost every child is evil. The court even pointed out that had the incident occurred on the playground instead of in the classroom, the result might well have been a finding of no liability. ${ }^{91}$ Kicks in the classroom may be worse than those on the playground because the former involve a greater breach of decorum or good order. Nevertheless, it strikes us as highly arbitrary to have the defendant's liability turn on where the kick occurred..$^{92}$

Once the Vosburg plaintiff's extraordinary loss is recognized as a negative windfall that nobody could reasonably have expected or prevented, the case for splitting responsibility for the windfall between the two boys (or their families) strikes us as compelling. (Of course, the kicker would also be solely liable for the foreseeable losses that accompany such a kick-in this case, zero.) Again, the underlying symmetry of the parties' positions provides a strong basis for this intuition. Both parties were equally and appropriately ignorant of the possible consequences of the kick. Instead, the bad consequences were simply an instance of random misfortune that came from nowhere and landed on the dyad of the kicker and the kicked.

\section{IV \\ DOCTRINAL INTEGRITY}

As suggested by our earlier examples, windfalls occur in many areas of law, including property, tort, and contracts. Because contractual liability is premised on the voluntary assent of bargaining parties, contract law must regularly face problems that arise when reasonable

\footnotetext{
90 Id. at $* 7$.

91 Vosburg v. Putney, 50 N.W. 403, 403-04 (Wis. 1891).

92 See Gail D. Hollister, Using Comparative Fault to Replace the All-or-Nothing Lottery Imposed in Intentional Tort Suits in Which Both Plaintiff and Defendant Are at Fault, 46 VAND. L. REV. 121 (1993), for a convincing argument for allocating liability according to comparative fault, even in intentional torts. Our claim is that at least in some cases that are denominated intentional torts, there is really no fault on the part of either party for at least some portion of the harm. Hence, at least in these cases, there are good reasons for splitting the liability evenly between the parties, as Hollister suggests. See id. at 127-32 (arguing that applying comparative fault in most kinds of intentional torts cases advances fairness and avoids unjust enrichment).
} 
ignorance affects the quality of the parties' assent. This makes contract law a natural laboratory for testing our theories about the proper scope and content of the split-the-difference remedy. Our normative thesis is simple: A combination of a split-the-difference remedy and the windfall principle can help bring much-needed clarity to some of the most tortured areas of contract law. This should not be surprising since, in our view, the existing doctrinal confusion stems from the law's failure to acknowledge the presence of windfalls. Similar doctrinal snafus could doubtless be cleared up in other areas of the law; following our discussion of contract doctrine, we discuss two such areas from property and tort.

People enter into contracts with reasonable assumptions, but when those assumptions prove erroneous, their expectations are frustrated. ${ }^{93}$ The difficulties that follow when parties enter contracts with reasonable ignorance of important matters engender some of the most famously confused doctrines of contract law: mistake, ambiguous commitment, impracticability, and frustration of purpose. The main reason that courts have such a hard time explaining themselves clearly when they apply these doctrines is that when mistakes, ambiguous assent, impracticability, or frustration occur, one of the two equally blameless parties will reap a windfall under an all-or-nothing regime. Yet courts and commentators alike agree that performance should be excused under these doctrines only when performance would result in an unanticipated burden or benefit and when the prospect of excuse would not lead people entering into agreements in the future to act inappropriately ${ }^{94}$ - in other words, when a windfall is present. Thus, the rules that determine whether to discharge a contract for mistake, ambiguous commitment, impracticability, and frustration of purpose screen for situations in which a split-the-difference remedy is appropriate. Indeed, while courts have been reluctant to adopt the splitthe-difference approach, they would find these doctrines easier to apply and explain than their chosen alternatives if they gave such splitting remedies when indicated.

While property and tort doctrines do not screen for windfalls as neatly as contract doctrines, there are several types of cases in which windfalls often arise. After exploring the contours of the splitting remedy in contract law, we will take up the theme of windfalls in two doctrines from property and tort: found property and proximate

93 See FARnsworth, supra note 84, § 9.1, at 599 (providing overview of "the problems that arise when one of the parties seeks to be excused from performing on the ground that one of that party's assumptions has turned out to be incorrect").

94 See generally Melvin A. Eisenberg, Mistake in Contract Law, 91 CAL. L. Rev. 1573, 1629-41 (2003) (discussing limitations on general relief principle). 
cause. These two doctrines often address cases in which a windfall exists and a splitting remedy is therefore appropriate.

\section{A. Mutual Mistake}

Under the doctrine of mutual mistake, a contract is not enforceable if, at the time it was entered into, both parties shared a mistaken basic assumption that had a material effect on their exchange, unless the risk of the mistake is properly allocated to one party. ${ }^{95}$ As we demonstrated in our discussion of Sherwood $v$. Walker, ${ }^{96}$ when courts refuse to enforce a contract because of a mutual mistake, the split-thedifference remedy is superior to any alternative. ${ }^{97}$ We hasten to say that we do not defend the existing doctrine of mistake but argue only that if performance is to be excused because of mistake, then the value of the mistake should be split.

While the precise parameters of the doctrine of mutual mistake are notoriously uncertain, ${ }^{98}$ its two essential elements track our test for a split-the-difference remedy. First, the doctrine affords relief only when enforcement of the contract would produce a windfall. The parties must be mistaken in a basic assumption, and the mistake must have a material effect on the exchange.

It is not enough for [a party seeking to avoid a contract for mutual mistake] to prove that he would not have made the contract had it not been for the mistake. He must show that the resulting imbalance in the agreed exchange is so severe that he can not fairly be required to carry it out. ${ }^{99}$

Second, the doctrine affords relief only when doing so would not create untoward ex ante effects. Relief will not be granted if one

95 Restatement (Second) of Contracts $§ 152(1)$ (1979); see also Farnsworth, supra note $84, \S 9.3$, at $605-14$ (discussing requirements set out by Restatement).

96 See supra p. 745-46 and notes 12-15, 87-88 and accompanying text.

97 Enforcement in Sherwood would have visited a windfall gain on the buyer. In other cases in which the mutual mistake doctrine has excused performance, enforcement would have resulted in a windfall loss. See, e.g., Dover Pool \& Racquet Club v. Brooking, 322 N.E.2d 168, 170 (Mass. 1975) (finding mutual mistake when change in zoning laws made construction impossible). In other cases, of course, enforcement would yield a windfall gain to one party and a loss to the other. See, e.g., Aluminum Co. of Am. v. Essex Group, 499 F. Supp. 53, 64-65 (W.D. Pa. 1980) (finding mutual mistake when costs dramatically rose for aluminum producer and caused tremendous losses on long-term contract). As the Restatement (Second) of Contracts explains, typically when a contract is voided for mutual mistake, enforcement would be significantly less desirable than expected for one party and materially more advantageous than expected for the other. RESTATEMENT (SECOND) OF CONTRACTS $\S 152 \mathrm{cmt}$. c.

98 See FARnsworth, supra note 84, §9.3, at 605 ("The cases in which an adversely affected party has been allowed to avoid the contract on this ground are not marked by their consistency in either reasoning or result.").

99 Restatement (Second) of Contracts $§ 152 \mathrm{cmt}$. c. 


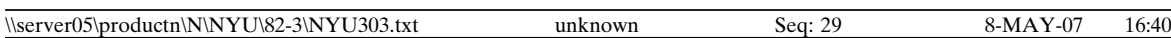

party has agreed to bear the risk of the mistake or is better situated to judge or minimize the risk. ${ }^{100}$ Courts must be careful with the doctrine of mutual mistake (as well as the other contract law doctrines discussed below), because their erroneous application of it will have adverse ex ante effects. If parties expect to be relieved of the consequences of their mistakes, they may be insufficiently careful. The doctrine of mistake recognizes this risk, and thus mutual mistake excuses performance only when neither party is properly accountable for that mistake-in other words, when excusing performance will have no perverse ex ante effects.

Whenever a party raises the mistake defense-or any of the contract doctrines discussed herein-the court must balance respect for the parties' agreed-upon terms against the unfairness of the windfall. If the remedy for mutual mistake is to void the contract, the court must sacrifice one or the other of these values however it determines the matter. Faced with that quandary, courts confronting a mutual mistake often give the entire windfall to one party or the other and then explain themselves by citing doctrine that turns on nebulous distinctions-as in the attempt to distinguish between the "nature" and "quality" of a cow in Sherwood.101 Other courts have occasionally grappled more directly with the tension presented by mutual mistake, rejecting an all-or-nothing rule in favor of a tailored remedy that adjusts for the mistake and allocates the windfall between the two parties. ${ }^{102}$ Thoughtful commentators have suggested that courts do so more often, ${ }^{103}$ and the Restatement suggests that the possibility of alternative relief is relevant in determining whether to void a contract

100 See id. $\S 154 \mathrm{cmts}$. a, d \& illus. 5 (stating that seller of land bears risk that land may contain valuable minerals, and builder bears risk of mistake as to conditions); FARNSwORTH, supra note $84, \S 9.3$, at 612 (suggesting that mistake defense is not allowed when it relates to fact as to which one party has superior expertise).

101 Sherwood v. Walker, 33 N.W. 919, 923-24 (Mich. 1887).

102 See, e.g., Nat'l Presto Indus., Inc. v. United States, 338 F.2d 99, 111-12 (Ct. Cl. 1964) (ordering sharing of additional expenses incurred by contractor to supply weaponry to government when equipment originally contemplated by both parties proved insufficient to perform agreement); Aluminum Co., 499 F. Supp. at 91-93 (substituting court-modified price term in light of unexpected inflation that greatly raised price of aluminum).

103 See, e.g., Lon L. Fuller \& Melvin Aron Eisenberg, Basic Contract Law 785-86 (8th ed. 2006) (stating that courts have power to apportion losses following impracticability); John P. Dawson, Judicial Revision of Frustrated Contracts: The United States, 64 B.U. L. REv. 1, 21 \& n.48 (1984) (citing commentators who argue that courts should simply divide losses between parties in no-fault cases in which rational solution cannot be found); Young, supra note 38, at 34-35 (arguing that courts can award half measures in cases where they are unable to accurately apportion blame or merit). 


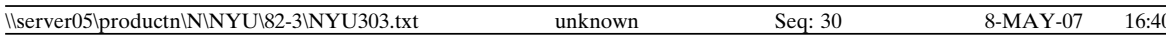

for mutual mistake. ${ }^{104}$ Courts would be able to address the fundamental conflict presented by mistake cases more thoughtfully and consistently if they were willing to compromise on remedies; and if they do so, they should admit that they are doing it.

\section{B. Ambiguous Commitment}

Another famous problem of contract law arises when the parties to an agreement use vague or ambiguous terms so that they think they are in agreement but later find that they were not. The classic case, of course, is Raffles $v$. Wichelhaus. ${ }^{105}$ Raffles involved the sale of cotton that was described in the contract as "to arrive ex 'Peerless' from Bombay" (Peerless being the name of the ship carrying the goods). ${ }^{106}$ It turned out, however, that there were actually two ships Peerless carrying cotton from Bombay, and a fall in the market price led the buyer to refuse the cotton that arrived on the second ship. The buyer argued that the contract referred to the Peerless sailing in October, whereas the seller insisted it was regarding the one sailing in December. ${ }^{107}$

Cases like this pose a difficult problem because whichever meaning the court chooses imposes a burden on one of the parties that that party did not think it was assuming and would not have voluntarily undertaken. Holding the contract void just because each party is blameless does not solve the problem. To the extent either party relied on the contract, he will suffer injury from its invalidation. In Raffles, for example, the buyer might have had to cover at a higher price when the October Peerless arrived, or the seller might have had to sell at a lower price when he found the buyer would not buy his cotton. ${ }^{108}$ When neither party is a better bearer of that risk, the parties should share the loss. ${ }^{109}$

As with the doctrine of mistake, the law of ambiguous commitment identifies those cases in which a windfall is present and neither party should bear it. Put succinctly, the rule is that there is no con-

104 Restatement (Second) OF Contracts $§ 152(2)$ ("In determining whether the mistake has a material effect on the agreed exchange of performances, account is taken of any relief by way of reformation, restitution, or otherwise.").

105 (1864) 159 Eng. Rep. 375 (Exch. Div.).

106 Id. at 375.

107 Id. The seller also argued that in any event the disagreement of the parties was not sufficient to void the contract, but the court disagreed. Id.

108 For an extensive discussion of the facts surrounding Raffles, see A.W. Brian Simpson, Contracts for Cotton to Arrive: The Case of the Two Ships Peerless, 11 Cardozo L. Rev. 287, 293-308 (1989).

109 See Eisenberg, supra note 94, at 1613 (describing situations in which cost-sharing is appropriate). Professor Eisenberg does not agree with us that windfall gains should be split, however. See id. at 1638-41 (proposing that "a windfall normally should be allocated to the party who is in possession when the windfall is discovered"). 


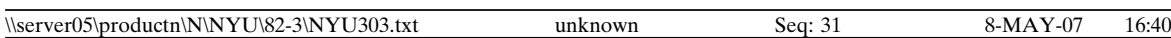

tract when parties reasonably attach materially different meanings to their words and neither has a reason to know the meaning attached by the other. ${ }^{110}$ The requirement that the difference in meaning be material identifies cases in which enforcement of the contract would create a windfall. ${ }^{111}$ The limitation of the doctrine to situations in which neither party could better address the ambiguity, and neither knew that the other's meaning differed from its own, assures that the prospect of splitting will not have any negative ex ante effects. As with mutual mistake, the law of ambiguous commitment screens for just the cases in which a split-the-difference remedy is appropriate.

\section{Impracticability and Frustration of Purpose}

Under the related doctrines of impracticability and frustration of purpose, courts sometimes excuse performance of a contract when its purpose is frustrated or its performance is made impracticable by the occurrence of an event that the parties had assumed would not occur. ${ }^{112}$ The parameters of these doctrines are as imprecise as those of mistake and ambiguous assent; ${ }^{113}$ but, as with those doctrines, the excuse is generally available only when a windfall is present, making a split-the-difference remedy appropriate.

The case for splitting damages under the doctrines of impracticability and frustration of purpose can be illustrated by a variation on another set of chestnuts, the Coronation Cases. ${ }^{114}$ When the coronation of King Edward VII was postponed in 1902, a number of people who had agreed to rent rooms from which to watch the procession at suitably enhanced rates successfully resisted paying what they had

\footnotetext{
110 Restatement (Second) of Contracts $§ 201 \& \mathrm{cmt}$. d (1979).

111 If a term of little consequence is ambiguous, a court may have to deal with the ambiguity but the contract is still enforceable. Id.

112 See U.C.C. $\S \S 2-613,2-615$ (2002) (establishing doctrines of contract avoidance for casualty to specified goods and excuse for failure of presupposed conditions); Restatement (SECOND) OF Contracts $§ \S 261,265,266$ (recognizing impracticability and frustration of purpose as discharging remaining contract duties); FARNSwORTH, supra note 84 , §§ 9.5-9.9, at 619-47 (discussing development of doctrines of impracticability and frustration of purpose).

113 In American Trading \& Production Corp. v. Shell International Marine Ltd., 453 F.2d 939 (2d Cir. 1972), an opinion rejecting an impracticability defense raised by a ship owner seeking additional compensation for expenses it incurred after the Suez Canal was closed in June 1967, the court concluded its opinion with the observation that "[m]atters involving impossibility or impracticability of performance of contract are concededly vexing and difficult. One is even urged on the allocation of such risks to pray for the "wisdom of Solomon." ' Id. at 944 (quoting 6 Arthur Linton Corbin, Corbin on Contracts $\S 1333$, at 372 (1962)). We believe that in the cases we discuss, Solomon would have concluded that wisdom indeed requires cutting the baby in half.

114 Chandler v. Webster, [1904] 1 K.B. 493; Griffith v. Brymer, (1903) 19 T.L.R. 434 (K.B.); Krell v. Henry, [1903] 2 K.B. 740.
} 
agreed. As these cases presented themselves, they were not good candidates for a compromise remedy because there was no windfall: The coronation and procession were only postponed, and thus the prospect of a good view of the procession was preserved-albeit with a delay-so the room owners could realize their profits later. Suppose, however, that the coronation had been canceled and not merely postponed. Who should have suffered the loss?

One solution would have been to have the renters forfeit their fifty percent deposits and leave it at that. In fact, some of the cases turned out this way since some renters gave up trying to recover their deposits. However, the deposits were presumably intended to give the landlords some protection against the renters' failure to pay rather than to allocate the risk of a cancellation (or postponement) of the coronation, the prospect of which was remote when the parties made their agreements. Forcing the deposit to do double duty as a response to both nonpayment and cancellation risks would presumably violate the expectations of the parties and in any event would undermine the value of the deposit as a protective device. ${ }^{115}$

Another approach would have excused the renters from paying because there was no deadweight loss, since the coronation was only postponed, not cancelled. ${ }^{116}$ Thus, an award to the owners would have yielded the unjust enrichment of their getting their profits twice. However, that is neither the way the courts explained their decisions nor the way the cases have been understood. The Coronation Cases would have excused the renters had the procession been cancelled. ${ }^{117}$

115 In the context of macroeconomic policy, it is well understood that the same policy tool cannot be used to influence more than one target. "Every student now knows that an equal number of instruments and targets is a necessary condition for the existence of policies capable of reaching specified targets." A.J. Hughes Hallett, Econometrics and the Theory of Economic Policy: The Tinbergen-Theil Contributions 40 Years On, 41 OXFord ECON. PAPERs 189, 189 (1989) (discussing insights attributed to Jan Tinbergen). For example, the government cannot rely on monetary policy to control both inflation and unemployment; an additional tool (such as fiscal or exchange rate policy) is needed to achieve a second objective. Similarly, if one wishes to allocate or control both the risk of nonpayment by renters and the risk of cancellation, a single tool-the deposit-cannot do a satisfactory job.

116 John D. Wladis, Common Law and Uncommon Events: The Development of the Doctrine of Impossibility of Performance in English Contract Law, 75 GEO. L.J. 1575, 1619 (1987). In defending the forfeiture of deposits in the Coronation Cases, Kull misses this point. Kull, supra note 31, at 22-27.

117 See R.G. McElroy \& Glanville Williams, The Coronation Cases, 4 Mod. L. Rev. 241, 245, 249 (1941) (arguing that "non-happening" of coronation was adequate grounds for finding renter not liable to pay). Indeed, the Restatement's illustration based on the Coronation Cases has the coronation cancelled. See Restatement (SEcond) of ConTRACTS $\S 265$ illus. 1 (stating that party who agrees to rent window to view parade that is then cancelled is not liable for breach of contract if he refuses to use or pay for window). 
The agreements were discharged because, to paraphrase the Restatement, the renters' principal purpose in renting the rooms was substantially frustrated without their fault by the postponement of the procession, the holding of which was a basic assumption on which the contract was made. ${ }^{118}$ In any event, windfall losses or gains frequently accompany situations in which frustration or impracticability lead courts to excuse further performance. ${ }^{119}$ Courts often provide some remedy to adjust the burden of such windfalls even after discharging the contract. ${ }^{120}$

Unfortunately, these adjustments are subject to a variety of constraints that limit flexibility and sometimes fail to prevent one party from bearing all of the loss. ${ }^{121}$ As explained in Part II, where parties exchanged a valuable interest that turned out to be worthless, and neither party was a better bearer of the risk of cancellation than the other, fairness and efficiency suggest that the parties should simply split the windfall loss.

\section{Found Property}

The doctrinal distinction between lost and mislaid property is among the most problematic in property law. ${ }^{122}$ Under the traditional approach, a finder of "lost" property is entitled to keep it, but a finder of "mislaid" property is supposed to turn the property over to the

118 See Restatement (Second) of Contracts § 265 (explaining that party's remaining contractual duties are discharged when his "principal purpose is substantially frustrated without his fault by the occurrence of an event the non-occurrence of which was a basic assumption on which the contract was made").

119 This was the situation in the landmark case of Taylor v. Caldwell, (1863) 122 Eng. Rep. 309, 312, 315 (Q.B.) (finding that accidental fire excused defendant's promise to provide use of facilities despite plaintiff's loss of advance payment for advertising and preparation); see also 20th Century Lites, Inc. v. Goodman, 149 P.2d 88, 90 (Cal. Ct. App. 1944) (finding that government order prohibiting outside illumination excused defendant's failure to pay rent to plaintiff for neon sign installations even though signs still benefited defendant's business); Alfred Marks Realty Co. v. Hotel Hermitage Co., 156 N.Y.S. 179, 180 (App. Div. 1915) (excusing defendant from liability to plaintiff for cost of still-valuable advertisements after unforeseen postponement of yacht race); Blount-Midyette \& Co. v. Aeroglide Corp., 119 S.E.2d 225, 226 (S.C. 1961) (finding that destruction of grain elevator that defendant had been hired to improve entitled plaintiff to full refund even though defendant had nearly completed job).

120 See U.C.C. $\$ 2-615 \mathrm{cmt}$. 6 (2002) (noting that where "neither sense nor justice is served by either answer when the issue is posed in flat terms of 'excuse' or 'no excuse,'" courts should make appropriate adjustments); Restatement (SECOND) OF Contracts $\S 272$ (inviting courts to ignore stated rules when those rules "will not avoid injustice").

121 See FArnsworth, supra note 84, § 9.9, at 645-47 (explaining contours and constraints of partial impracticability, divisibility, restitution, and equitable adjustment).

122 See, e.g., Helmholz, supra note 44, at 313 ("Even the leading decisions [on the distinction between lost and mislaid property] are so uncertain in their rationale that it is difficult to fit new fact situations into established patterns."). 
owner of the locus in quo (the place where the item was found), who gets conditional ownership. ${ }^{123}$ The differential treatment of lost and mislaid property is allegedly justified by reference to the expectations of the true owner of the find. ${ }^{124}$ Based on this distinction, a pocketbook found on the counter of a barbershop is mislaid property that must be surrendered to the shop owner, while a wallet found on the floor of a café is lost property to be retained by the finder.

Commentators have long been troubled by the distinction between lost and mislaid property, and many of them have pointed out that it rests on questionable assumptions about the state of mind of the true owner and the ability of the finder of the property to discern its status and act accordingly. ${ }^{125}$ As early as 1939, a student comment proposed that the distinction between lost and mislaid property should be abolished altogether and replaced with a rule under which "the owner of the locus in quo ... and the finder [would] share in the goods equitably."126 In reviewing this proposal, Professor Richard Helmholz found much to commend in it:

First, adoption of the proposal would not be unprecedented. Roman law, which has shaped much of the common law of personal property, employed a similar rule of equitable division. Second, the rule provides an equitable way to resolve competing claims that are apt to be about equally strong. It comports with what one instinctively feels to be fair. Third, the rule avoids the fine and artificial distinctions that the law has created between lost and mislaid prop-

123 See, e.g., Foulke v. N.Y. Consol. R.R., 127 N.E. 237, 239 (N.Y. 1920) (explaining that it was railway company's "right and duty to possess and use the care of a gratuitous bailee for the safe-keeping of the package until the owner should call for it"); Ray v. Flower Hosp., 439 N.E.2d 942, 945 (Ohio Ct. App. 1981) (explaining that mislaid property is presumed to be left in custody of owner of premises until true owner is located).

124 In the case of mislaid property, it is presumed that the owner intentionally laid the object down at some place and then accidentally forgot to pick it up. When the owner subsequently realizes her mistake, she is expected to return to the locus in quo to reclaim the object. Therefore, leaving the object with the owner of the locus in quo will aid the true owner in her efforts to retrieve the good. See, e.g., McAvoy v. Medina, 93 Mass. (11 Allen) 548, 549 (1866) (discussing duty of barbershop owner to take care of mislaid pocketbook). In the case of lost property, on the other hand, the true owner has no recollection of the precise place and time the object left her possession and accordingly will not know where to look for it. Hence, entrusting the object to the finder will have no effect on the search efforts of the owner, who in this case is presumed to have no inkling where to look. See Foulke, 127 N.E. at 238 (discussing difference between "lost" and "mislaid" property); Joseph William Singer, Property Law 96-97 (3d ed. 2002) (same).

125 See Ray Andrews Brown, Law of Personal Property § 3.4, at 29 (Walter B. Raushenbush ed., 3d ed. 1975) ("The doctrine of misplaced goods is apt to be artificial, difficult to apply, and doubtful in principle.").

126 Comment, supra note 45, at 237. 


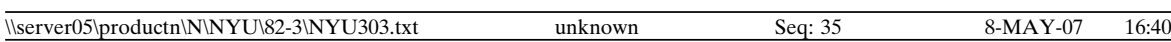

erty. It is not so open to dispute, manipulation, and criticism as are the traditional categories. ${ }^{127}$

Helmholz also noted that even though the proposal has not been adopted in any reported case, ${ }^{128}$ "the evolution of recent case law opens the possibility of a brighter future for equitable division than it has enjoyed in the past." 129 We agree.

Both the original comment and Helmholz call for the splitting of the value of the find on two grounds that we have already stressed: equity and doctrinal clarity. Our analysis complements their rationales by providing an efficiency justification for splitting. If found property cases are divided equally between lost and mislaid property, ${ }^{130}$ then in half of the cases the finder gets the full value of the object and the owner of the locus in quo gets nothing, and in the other half the owner of the locus in quo gets the full value and the finder gets nothing. This means that ex ante, each party has a fifty percent probability of receiving the value of the find. Ex post, however, one of them will receive the entire value and the other will receive nothing. Because people are generally risk averse, both parties are likely to prefer to get half of the value with complete certainty over a fifty percent chance of getting the entire value. ${ }^{131}$ We join prior commentators in arguing that a splitting solution will bring doctrinal coherence to the law of found property and finally will rid us of the dubious distinction between lost and mislaid property.

Extending splitting to the found property context would not violate our "no-ex-ante-effects" requirement, which is a critical premise of the argument that splitting windfalls promotes efficiency. ${ }^{132}$ It is possible-though unlikely-that changing the rules for who gets to keep found objects might alter parties' incentives to search for such property. ${ }^{133}$ But even if such a change made owners inspect their premises more (or less) often or finders look more (or less) assidu-

127 Helmholz, supra note 44, at 315 (footnotes omitted).

128 Id.

129 Id. at 322.

130 This assumption is likely to obtain in these cases since courts apparently choose between the categories completely arbitrarily. See supra notes 44-46 and accompanying text.

131 See supra notes 71-78 and accompanying text (describing cost of uncertainty in context of windfall cases).

132 See supra notes 32-33 and accompanying text (noting that windfalls, by definition, do not alter ex ante windfall-creating behavior, as illustrated in discussion of classic cases).

133 Since the distinction between lost and mislaid property is so murky, and since most people do not know the state of the law, it strikes us as unlikely that splitting all found property would change anyone's behavior. 
ously for lost items, the consequences would be almost entirely distributional. ${ }^{134}$

\section{E. Windfall Losses in Tort}

We believe that a splitting remedy could also play an enhanced role in tort disputes. Of course, tort is the one area of common law where splitting remedies are already widely deployed, under the rubric of "comparative negligence." Our proposal thus necessarily has more limited scope in the tort context, since splitting remedies are already applied much more broadly than the limited windfall context that we propose. ${ }^{135}$ There is room, however, for additional splitting in cases of completely unforeseeable losses. Although there is no set of doctrinal categories that conveniently singles out such windfall losses-as we argued was the case with contract law-we can use Palsgraf v. Long Island Railroad Co. ${ }^{136}$ as an example of the kinds of windfall losses that should be split.

As every tort student knows, Palsgraf involved a woman waiting on a platform for her train to arrive. While she was waiting,

[a] train stopped at the station, bound for another place. Two men ran forward to catch it. One of the men reached the platform of the car without mishap, though the train was already moving. The other man, carrying a package, jumped aboard the car, but seemed unsteady as if about to fall. A guard on the car, who had held the door open, reached forward to help him in, and another guard on the platform pushed him from behind. In this act, the package was

134 What about the possibility, as suggested by Amanda Goodin, that a rule leaving mislaid property with the owner of the locus in quo would increase the likelihood that the true owner would reclaim the item in question? We think this is unlikely for two reasons: First, most people who have not been to law school-and many who have-have not heard of or do not understand the distinction between lost and mislaid property. Whatever rules govern this allocation will likely be unknown to almost everyone. Second, no matter what rules apply, anyone is free to ignore them dishonestly. So, for example, an unscrupulous finder who discovers what is now termed "mislaid" property is always free to keep it without informing the owner of the place where it was found. Such cases are not litigated, of course, because no dispute between finder and locus owner ever emerges. That would not change under our rules, but what would change is the allocation of disputed finds between locus owner and finder when the finder has not chosen (or been able) to conceal his find.

135 Whether the widespread use of comparative negligence principles in tort is in fact desirable is still somewhat controversial. See, e.g., Oren Bar-Gill \& Omri Ben-Shahar, The Uneasy Case for Comparative Negligence, 5 Am. L. \& ECON. Rev. 433, 444-54 (2003) (criticizing division-of-liability principle under comparative negligence regime on efficiency grounds). We believe our limited proposal for splitting avoids much of the criticism raised by Bar-Gill and Ben-Shahar because we limit splitting to windfalls-where, by definition, the windfall-generating event is so unlikely that no rule is likely to generate symmetric precautions (or any other ex ante change in behavior).

136162 N.E. 99 (N.Y. 1928). 


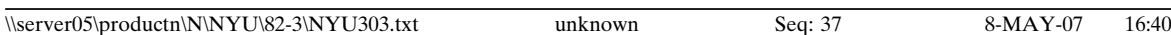

dislodged, and fell upon the rails. It . . contained fireworks, but there was nothing in its appearance to give notice of its contents. The fireworks when they fell exploded. The shock of the explosion threw down some scales at the other end of the platform, many feet away. The scales struck the plaintiff, causing injuries for which she sue[d]. ${ }^{137}$

Since the defendant did not behave negligently and the court declined to impose strict liability for such accidents, the loss was left where it fell—on the plaintiff. 138

We think that a better solution could have been achieved in Palsgraf if the court had realized that not only was the accident not the result of the defendant's negligence, it was not the result of the plaintiff's negligence either-in other words, it was a windfall. Sometimes accidents happen even when all parties are being as careful as we would ever want them to be. If in such cases accidents nevertheless occur, it seems to us that a fair and efficient solution would be to split the losses. Because the harm to Mrs. Palsgraf was so unforeseeable, we would not expect the railroad or its agents to exercise any more care in preventing it than they did. But neither does it seem appropriate for the victim to go utterly uncompensated for what was an obvious loss from her perspective.

In instances like Palsgraf, where the harm is completely unexpected and impossible to anticipate, and where there is contractual privity between the parties, splitting the difference would impose twoway strict liability between the parties for half of the total harm. It would force the victim to bear half of the loss while shifting the other half, at least initially, to the injurer. That is unlikely to be the end of the story, however. In this context, the railroad would factor its expected liability into ticket prices, charging every passenger a little more to cover the rare cases of (split) liability for its nonnegligent actions that caused unforeseeable harms. From a loss-spreading perspective, it would thus seem that splitting is an inferior remedy to strict liability. In cases where there is no contractual privity between the victim and injurer, however, the defendant could not shift the cost of the plaintiff's unforeseeable injuries to any wider group of customers. In such instances, splitting the plaintiff's loss would result in true loss sharing between the victim and injurer.

In cases such as Palsgraf and Vosberg, where injuries to a plaintiff are so unforeseeable as to constitute a windfall, sharing the cost of the plaintiff's injuries is in keeping with our basic notions of fairness for

137 Id. at 99.

138 Id. at 101. 


\begin{tabular}{|c|c|c|c|}
\hline 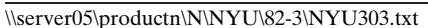 & unknown & Seq: 38 & 8-MAY-07 \\
\hline
\end{tabular}

unforeseeable accidents. And, so long as the accidents at issue are true windfalls, there will be no ex ante effects on precaution or activity levels regardless of how we decide to allocate the harms that result.

\section{$\mathrm{V}$ \\ OBJECTIONS}

In this Part, we address the leading objections to compromise remedies. In particular, we identify and largely reject five classes of objections based on (a) judicial incentives, (b) the integrity of the judicial system, (c) the extent of redistribution, (d) the availability of contractual solutions such as force majeure clauses, and (e) valuation problems.

\section{A. Judicial Incentives}

Even if we are correct about the appropriate way to allocate windfalls once they have been identified, an objection to our normative thesis might be that we give judges too much discretion to identify those situations where windfalls do in fact exist, and that judges will do a bad job of performing this task. Jon Elster is typical of the critics in writing that:

One of the reasons ... compromises ... occur so rarely is [that] ....

[j] udges might take their task less seriously if they did not have to come up with a clear-cut and definite interpretation of the law, or a clear and unambiguous statement of the facts. A judge is not paid to throw up his hands and say that since the law offers no guide to the decision, he will impose a compromise or . . . take account of such other considerations as seem relevant. ${ }^{139}$

Indeed, the idea that a winner-take-all rule provides appropriate incentives for fact finders to work hard to arrive at the correct result is probably the key objection to compromise remedies in the minds of most writers on this subject. ${ }^{140}$

To decide whether this objection is compelling, however, we need to consider two questions: First, will the option to deploy a new splitthe-difference remedy cause judges to work less diligently at deciding which party should actually win? And second, what would be the consequences of such behavior if in fact it did occur? We conclude that slacking off is unlikely. Moreover, even if it did become more

139 Jon Elster, Solomonic Judgments: Against the Best Interest of the Child, 54 U. CHI. L. REv. 1, 29 (1987).

140 Coons also points out that abandonment of the winner-take-all rule could lead to "[t]emptations to the trier of fact." Coons, supra note 47 , at 761 ; see also supra note 54 . 


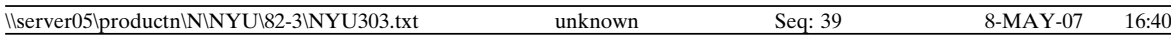

common, a split-the-difference regime might actually reduce net error costs.

\section{Will the Availability of Splitting Lead Judges to Slack Off?}

There is little reason to think judges will be systematically biased toward finding windfalls when they do not in fact exist. Even if one assumes that judges are effort minimizers, ${ }^{141}$ finding a windfall does not seem to require substantially less judicial effort than deciding a case on an all-or-nothing basis. Judges would still have to justify their conclusion that there is a windfall in order to effect a split-the-difference remedy under our system, exactly as they have to decide which of the two parties should prevail under the status quo. Decisions will still have to be described in judicial opinions that provide warrant for their holdings, and these decisions will still be reviewable under the same criteria that appellate courts now use.

Moreover, parties will still have every reason to argue vigorously that they should prevail, even when splitting the difference is a possible remedy. Hence, the quality of evidence or legal argument presented to the fact finder should not be any different under a compromise remedy regime as compared with the status quo.

While we cannot be certain that our proposal would produce no additional error costs, it seems unlikely that it will introduce any systematic errors. Split-the-difference remedies constrained by the windfall principle offer judges only a limited amount of additional freedom. Judges are not being authorized to find a new cause of action or to introduce novel procedures. Rather, splitting the difference is a combination of the traditionally permissible remedies: finding for the plaintiff and finding for the defendant.

\section{Error Creation or Error Correction?}

Most critics of the split-the-difference remedy implicitly assume that the status quo, winner-take-all remedy occurs in a world of perfect decisionmaking without any possibility of judicial error. ${ }^{142}$ Even

141 See Richard A. Posner, What Do Judges Maximize? (The Same Thing Everybody Else Does), 3 Sup. Cт. Econ. Rev. 1, 3 (1993) (contending that federal appellate judges are rational maximizers whose behavior can be viewed as composite of rational maximization of nonprofit enterprise manager, voter, theatrical spectator, and player of games).

142 But see Abramowicz, supra note 56, at 238, who writes that: In evaluating compromise verdicts, we must necessarily consider the uncertainty that pervades legal decision making. In the guise of simplification, legal scholarship often ignores the possibility that [fact finders] may err in determining whether the defendant engaged in alleged conduct, or acknowledges only that there may be some tradeoff between [false positives and false negatives]. Such error, however, cannot merely be dismissed as an unfortunate 
when errors are taken into account, the analysis usually focuses only on the possibility of errors rather than on their relative costs. But as we will see, not all errors are created equal.

To foreshadow what comes next, our somewhat counterintuitive claim is that even if the ability to render compromise or split-the-difference verdicts does lead to some additional errors by fact finders, the net effect of such misclassifications is actually likely to be positive because of the likely overlap between cases that are currently wrongly decided and incorrect splits, and because incorrect splits are a less serious error than an incorrect winner-take-all verdict. Hence, splitting actually offers the possibility of an error reduction mechanism if the errors created are outweighed by the errors minimized by a splitting approach.

Suppose that allowing splitting would lead compromise-happy judges to misuse their discretion, announcing split verdicts much more often than would be truly warranted. What are the consequences likely to be? Surprisingly, it turns out that even in this worst-case scenario-which we consider highly unlikely_the results might actually be a net improvement in welfare. A detailed explanation follows, but the key intuition is that if incorrect splits are likely to overlap with cases that would have been incorrectly decided under the status quo, then splitting can ameliorate, or at least will not exacerbate, judicial error.

Table 2: Outcomes of 10,000 Hypothetical Cases Under Different Rules for Deciding Windfall Cases (Erroneous

Decisions in Boldface)

\begin{tabular}{|c|c|c|c|c|}
\hline \multicolumn{5}{|c|}{$\begin{array}{l}\text { A: Status Quo-No Splitting Possible } \\
\text { (X indicates that splitting is not permitted) }\end{array}$} \\
\hline \multirow[b]{2}{*}{ Actual Outcome } & \multicolumn{3}{|c|}{ Correct Outcome } & \multirow[b]{2}{*}{ Total } \\
\hline & $\begin{array}{l}\text { Plaintiff } \\
\text { Should Win }\end{array}$ & $\begin{array}{l}\text { Defendant } \\
\text { Should Win }\end{array}$ & $\begin{array}{l}\text { Nobody } \\
\text { Should Win }\end{array}$ & \\
\hline Plaintiff Wins & 4500 & 450 & 50 & 5000 \\
\hline Defendant Wins & 450 & 4500 & $\mathbf{5 0}$ & 5000 \\
\hline Split & $\mathbf{x}$ & $\mathbf{X}$ & $\mathrm{X}$ & 0 \\
\hline Total & 4950 & 4950 & 100 & 10,000 \\
\hline \multicolumn{4}{|l|}{ Total Errors $(10 \%)$} & 1000 \\
\hline \multicolumn{4}{|c|}{ "Consequential Errors"* } & 900 \\
\hline
\end{tabular}

inevitability. ... [I]ts inclusion in our models of legal decision making must change our evaluation of how institutions should be structured. 


\begin{tabular}{|c|c|c|c|c|}
\hline \multicolumn{5}{|c|}{$\begin{array}{l}\text { B: Splitting Possible, Favorable Assumptions } \\
\text { (changes from Panel A in parentheses) }\end{array}$} \\
\hline \multirow[b]{2}{*}{ Actual Outcome } & \multicolumn{3}{|c|}{ Correct Outcome } & \multirow[b]{2}{*}{ Total } \\
\hline & $\begin{array}{c}\text { Plaintiff } \\
\text { Should Win }\end{array}$ & $\begin{array}{l}\text { Defendant } \\
\text { Should Win }\end{array}$ & $\begin{array}{c}\text { Nobody } \\
\text { Should Win }\end{array}$ & \\
\hline Plaintiff Wins & $\begin{array}{c}4500 \\
(0)\end{array}$ & $\begin{array}{c}350 \\
(-100) \\
\end{array}$ & $\begin{array}{c}25 \\
(-25)\end{array}$ & 4875 \\
\hline Defendant Wins & $\begin{array}{c}350 \\
(-100)\end{array}$ & $\begin{array}{c}4500 \\
(0)\end{array}$ & $\begin{array}{c}25 \\
(-25) \\
\end{array}$ & 4875 \\
\hline Split & $\begin{array}{c}\mathbf{1 0 0} \\
(+100)\end{array}$ & $\begin{array}{c}\mathbf{1 0 0} \\
(+100)\end{array}$ & $\begin{array}{c}50 \\
(+50) \\
\end{array}$ & 250 \\
\hline Total & 4950 & 4950 & 100 & 10,000 \\
\hline \multicolumn{4}{|c|}{ Total Errors $(9.5 \%)$} & 950 \\
\hline \multicolumn{4}{|c|}{ "Consequential Errors"** } & 800 \\
\hline
\end{tabular}

\begin{tabular}{|c|c|c|c|c|}
\hline \multicolumn{5}{|c|}{$\begin{array}{l}\text { C: Splitting Possible, Less Favorable Assumptions } \\
\text { (changes from Panel A in parentheses) }\end{array}$} \\
\hline \multirow[b]{2}{*}{ Actual Outcome } & \multicolumn{3}{|c|}{ Correct Outcome } & \multirow[b]{2}{*}{ Total } \\
\hline & $\begin{array}{l}\text { Plaintiff } \\
\text { Should Win }\end{array}$ & $\begin{array}{l}\text { Defendant } \\
\text { Should Win }\end{array}$ & $\begin{array}{l}\text { Nobody } \\
\text { Should Win }\end{array}$ & \\
\hline Plaintiff Wins & $\begin{array}{l}4450 \\
(-50) \\
\end{array}$ & $\begin{array}{c}400 \\
(-50)\end{array}$ & 25 & 4875 \\
\hline Defendant Wins & $\begin{array}{c}400 \\
(-50)\end{array}$ & $\begin{array}{l}4450 \\
(-50)\end{array}$ & 25 & 4875 \\
\hline Split & $\begin{array}{c}\mathbf{1 0 0} \\
(+100) \\
\end{array}$ & $\begin{array}{c}\mathbf{1 0 0} \\
(+100) \\
\end{array}$ & 50 & 250 \\
\hline Total & 4950 & 4950 & 100 & 10,000 \\
\hline \multicolumn{4}{|c|}{ Total Errors $(10 \%)$} & 1050 \\
\hline \multicolumn{4}{|c|}{ "Consequential Errors"* } & 900 \\
\hline
\end{tabular}

* "Consequential errors" are weighted errors. An incorrect split is assigned one-half the cost of a "full" error, and an incorrect failure to split is conservatively assigned no cost at all.

\section{a. Errors Under the Status Quo}

To see the consequences of allowing splitting, we start from the baseline in Panel A of Table 2, where splitting is not allowed. We imagine 10,000 hypothetical cases, in which true windfalls number only $100,1 \%$ of the total. Under common law rules, windfalls cannot be split, and so all of them must be decided incorrectly in favor of one party or the other. However, among non-windfall cases, most$90.9 \%$ - are correctly decided. Thus, of the 5000 pro-plaintiff verdicts in the first line, 4500 are correctly decided, 450 are cases that defendants should have won, and 50 are cases that should have been split. 


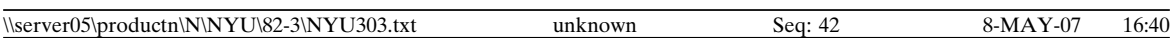

June 2007]

The same goes for the pro-defendant verdicts in the second line. (Incorrect outcomes are in boldface.)

To keep an overall score when there are different kinds of mistakes judges can make, we propose a crude measure, "consequential errors," which works as follows:

1. Each wholly incorrect decision (for the plaintiff when the defendant should win, or vice versa) counts as a full mistake;

2. Each partially incorrect decision (split when the plaintiff should win or split when the defendant should win) counts as a half mistake;

3. Each incorrect failure to split (the plaintiff or the defendant wins when the case is a true windfall that should be split) conservatively counts as no error at all. ${ }^{143}$

Our measure of consequential errors is simply a weighted sum of the different kinds of mistakes:

Consequential Errors $=(D$ wins $\mid P$ should win $)+(P$ wins $\mid D$ should win $)+$ $\frac{(\text { Split } \mid P \text { should win })+(\text { Split } \mid D \text { should win })}{2}$

In Panel A, then, there are 1000 total errors, but because we assign no weight to an incorrect failure to split, the total error cost ("consequential errors") is 900 .

\section{b. Errors Under Splitting}

Suppose we now allow splitting, and suppose that judges respond by recklessly overindulging in the discretion they have been granted. Instead of reaching 100 split verdicts, they hand down 250 , so that three-fifths of all split verdicts are actually mistakes that should have been decided for one party or the other. While this might sound bad, Panel B suggests that not only is it not a problem, but it actually represents an improvement over the status quo. The reason is that 200 of the 250 split verdicts in Panel B came from cases that would have been incorrectly decided even if splitting were forbidden, as in Panel A. That is, instead of 450 plaintiff victories that should have been defendant victories, we now have only 350 , and similarly for defendant victories that should have resulted in plaintiff wins. The 200 erroneous split verdicts are entirely drawn from these mistakenly decided cases.

This is not an implausible scenario. After all, it is precisely the close and doctrinally complicated cases that judges would be most inclined to split, and it is these very same cases that are most likely to

143 An incorrect failure to split arguably should count as a partially incorrect decision; our conservative measure underestimates the error costs of the current system relative to a system that allows splitting. 
be mistakenly decided if splitting were not permitted. On this analysis, splitting — even mistaken splitting — serves as a mechanism to correct errors, rather than creating additional errors. If the world looks like Panel B, introducing splitting will reduce the total number of errors made, because we can now correctly classify some windfalls that would have been awarded to one party or the other under the status quo rules. More importantly, however, we reduce the severity of those errors that are made: Each wrongful split comes from a case that would have been wrongly decided anyway. ${ }^{144}$ If one is going to make a mistake, it is better to make a smaller mistake than a larger one, and in Panel B, this is precisely what happens. Under our weighted measure of consequential errors, even when judges are excessively split-happy, as in Panel B, the number of errors made falls from 900 without splitting to 800 when splitting is allowed.

Instead of assuming that all of the 250 newly split cases would have been incorrectly decided in the absence of splitting, suppose that, as in Panel C, half of them would have been correctly decided under current rules. Even here, the net effects of the errors are no worse than under the status quo. Our consequential-errors measure demonstrates this: Total consequential errors in Panel $\mathrm{A}$ and Panel $\mathrm{C}$ are both 900. This confirms that although the Panel $\mathrm{C}$ scenario includes more errors, they are less serious on average, because the penalty for wrongly splitting is only half as severe as for wrongly deciding. (This is true even though our consequential-errors measure gives us no credit at all for correctly deciding fifty additional true-splitting cases.) $)^{145}$

Even in the unlikely scenario that judges incorrectly split a large number of cases, then, splitting still reduces total error costs. At best, splitting dramatically reduces current judicial errors both when splits are incorrect, by reducing the gravity of already existing errors, and when splits are correct, by reducing errors resulting from a failure to split. At worst, incorrect splits do not significantly reduce or increase current error costs, and correct splits do reduce errors from a failure

144 In addition, of course, introducing splitting does allow some true windfalls to be correctly decided, which is impossible under the status quo, so the total number of errors made may actually decrease.

145 A more negative scenario could be envisioned in which all split cases would have been correctly decided under the status quo, although this seems implausible. In that scenario, of course, the introduction of splitting looks much worse. Not only do total errors increase, but the effect of the errors is larger since now we are splitting formerly correct cases rather than formerly incorrect ones. As we suggested earlier, however, this extreme case strikes us as unlikely: Most wrongly split cases under our rules are more likely to have been wrongly decided under the status quo precisely because it is the close cases that any system is most likely to get wrong. 
to split under the status quo. In either scenario, splitting is an improvement.

\section{B. The Integrity of the Judicial System}

Several writers have suggested that splitting will tend to undermine the authority or integrity of the judicial system. By admitting the possibility that there is no winner, no single party who is right or wrong (or worse still, that the court cannot determine who is right), a split-the-difference remedy is sometimes alleged to erode public support for the necessary fiction that the law is always fair, just, and perfect. Coons reflects these views:

However shabby the syllogisms that support the final judgment, men can cling to it as to a plank in a shipwreck. It may seem all that separates them from the descent into the Maelstrom of uncertainty. For the law to callously recognize its own bafflement in a compromise judgment would appear a form of treason to its constituents. ${ }^{146}$

In a similar vein, Justice Brandeis is said to have explained that "[t]o be effective in this world you have to decide which side is probably right; and, once you decide, you must act as if it were one hundred per cent right." 147 An extended argument along similar lines is also made by Charles Nesson. ${ }^{148}$

Our claim is that these critics have things backwards, at least insofar as windfalls are concerned. Since it is precisely in these cases that neither party is at fault, it strikes us that it is the all-or-nothing remedy, rather than a compromise, that is likely to cast the judicial system into disrepute. As we explained in our discussion of doctrinal integrity, ${ }^{149}$ it is the pretense of certainty when dealing with windfalls, rather than the failure to acknowledge a clear winner, that has tended to undermine the wisdom and fairness of the judicial system. ${ }^{150}$ The

146 Coons, supra note 47 , at 771.

147 John E. Coons, Compromise as Precise Justice, 68 Cal. L. Rev. 250, 260 (1980) (internal quotation marks omitted). Coons attributes this statement to Professor Nathaniel Nathanson, who probably heard it from Thomas Corcoran, who apparently heard it from Justice Brandeis. Id. at 260 n.13.

148 Nesson, supra note 55, at 1359 ("The aim of the factfinding process is not to generate mathematically 'probable' verdicts, but rather to generate acceptable ones; only an acceptable verdict will project the underlying legal rule to society and affirm the rule's behavioral norm."); see also Laurence H. Tribe, Trial by Mathematics: Precision and Ritual in the Legal Process, 84 Harv. L. Rev. 1329, 1332, 1358-77 (1971) (arguing that costs of using mathematics in fact-finding process outweigh most benefits of such use).

149 See supra Part IV.

150 " $[\mathrm{T}]$ here does not seem to be any reason to suppose that a recognition of uncertainty would undermine faith in legal institutions. Perhaps the public would embrace legal institutions even more, out of a recognition that there are many difficult disputes that need resolution somehow." Abramowicz, supra note 56, at 260. Anyone who has taught or 
windfall cases are not, in Coons's terminology, cases of "doubt"151 but rather are cases of an affirmative reason for splitting.

Saul Levmore's comparative study of the treatment of good-faith purchasers of stolen goods in various legal systems ${ }^{152}$ provides anthropological support for our argument. His wide-ranging survey demonstrates that many different rules for dealing with conflicts between original owners and good-faith purchasers of stolen goods are possible, plausible, and defensible. The fact that different legal systems offer quite different doctrinal responses to the same problem suggests that no single solution is obviously optimal. ${ }^{153}$ It further suggests that nobody should be aggrieved or mistrustful if our judicial system formally comes to this conclusion as well.

In sum, the windfall principle provides ample justification for a split-the-difference remedy in specific cases. It is a justification that should strengthen, not weaken, the respect that an intelligent observer would have for the judicial system.

\section{Apportionment: Variable Splitting, Redistribution, and Insurance}

A different objection to our argument is that it does not go far enough. Why not split gains and losses between two people in something other than a fifty-fifty ratio? Furthermore, why should we split the windfall only between the immediate parties? Why not "socialize" windfalls by allocating them to society at large? This could be done, for example, by creating social insurance against negative windfalls and taxing positive ones. We address each of these questions in turn.

First, with regard to the apportionment of windfalls (positive and negative) between the parties, it is clear that the windfall should be split evenly between them. While continuously variable splitting may

studied the classic windfall cases should be sympathetic to this perspective since it is often reflected in students' intuitive responses to the cases: Every year, at least one Contracts student suggests that the cow in Sherwood should have been divided between the two parties.

151 See supra notes $47-50$ and accompanying text.

152 Levmore, supra note 25 (comparing diverse methods of resolving conflicts between original owners and good-faith purchasers of stolen property in several ancient and modern legal systems).

153 To be fair, Levmore does note that compromises between good-faith purchasers and original owners are not found in the legal systems he surveyed. See id. at 49-65 (discussing six different legal systems' treatment of good-faith purchasers). He suggests that this might be due to a valuation problem: In an all-or-nothing world, either the buyer keeps the stolen object or it is returned to the original owner. See id. at 64 (noting that "sharing rule" dividing stolen property leads to "significant valuation problems for the fact finder"). In either case, the most the court is ever required to do is transfer possession. Under a split-the-difference remedy, the court has to value the stolen object. As we note immediately below, however, there will often be a way to finesse this issue. 
be justified in some situations (such as comparative negligence), ${ }^{154}$ in windfalls it is not. By definition, a windfall is an "uncaused" or arbitrary gain or loss. Since neither the plaintiff nor the defendant can take the credit or blame for the windfall, it should simply be divided evenly between the two parties. ${ }^{155}$ In addition, our proposal makes fewer administrative demands on the dispute resolution system than would be the case under variable splitting because, by limiting splitting to true windfalls, we dramatically reduce the valuation problems fact finders must face. ${ }^{156}$

Second, windfall gains should be allocated between the parties, not captured by society for more general redistribution. Consider positive windfalls: If no one could have done anything to cause the windfall, why should we not simply appropriate it for social use? As Eric Kades points out, a tax on positive windfalls would be extremely efficient. ${ }^{157}$ Because taxes alter the relative costs and benefits of engaging in certain activities, taxes on activities over which individuals exercise control create incentives for individuals to modify their behavior in order to minimize their tax burden. ${ }^{158}$ In contrast, individuals cannot control the incidence of positive windfalls by substituting certain types of behavior for others-by definition, a windfall is a surprise to all involved. Arguably, then, positive windfalls are an ideal source of tax revenue because their taxation will not distort anyone's behavior.

The case for "socializing" windfalls is a strong one, at least in theory. However, there are at least two significant problems with this proposal, both having to do with the enforcement incentives such a regime creates. To begin with, as Kades pointed out, in order to avoid taxation, parties will be disinclined to report positive windfalls. ${ }^{159}$ Consider the pregnant cow in Sherwood. If both buyer and seller realized that there was a good chance that the state of Michigan would wind up with the cow-or more accurately, would confiscate the cow's

154 See, e.g., Bar-Gill \& Ben-Shahar, supra note 135, at 458-60 (situating variable standards of care for comparative liability regimes within larger set of mechanisms for achieving optimal allocation of liability).

155 This, of course, assumes that the parties are equally situated with respect to the windfall in question.

156 See infra note 176 and accompanying text.

157 Kades, supra note 31, at 1494-95.

158 Id. For example, income taxes induce people to work less than they otherwise would, and wealth taxes lead to less saving. Such distortion of private behavior "leads to economic losses above and beyond tax revenues": Society loses tax revenue, and the individual loses whatever subjective value he derived from engaging in his activity of choice. Id.

159 See id. at 1528 (highlighting incentive to conceal unexpected gains when tax rate is high). 


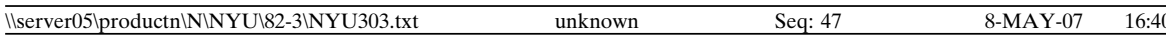

increased value via the tax system-the parties would have little incentive to bring the litigation in the first instance. Moreover, judges-or the administrative agency in charge of windfall allocation-would arguably have too great an incentive to find windfalls where none existed in order to generate revenues for the state. ${ }^{160}$

The opposite of taxing positive windfalls is to compensate for negative windfalls via some sort of social insurance mechanism. Again, if a loss is a true windfall, nobody could reasonably have done anything to prevent or reduce it. Why not allocate such losses to society at large rather than to the victim, the injurer, or the two together? Kades rejects the subsidization of windfall losses through a "reverse insurance" tax, claiming that such losses are adequately handled by private insurance. ${ }^{161}$ We are less optimistic than he is about the availability of private insurance for many kinds of issues, and so we are correspondingly more willing to allocate both gains and losses between the two parties to a lawsuit rather than trying to spread them more widely. It would be very difficult to design an insurance mechanism that fully addresses the problem of negative windfalls. Since windfalls come in so many varieties and are unknown to the parties in advance, we are skeptical that either the state or the private insurance market could adequately assess the relevant risk and provide sufficient coverage.

If positive windfalls could be identified without the efforts of disputants and/or the legal system, they would make an ideal source of tax revenue. Similarly, if the risk of negative windfalls could be allocated through an insurance market, we would welcome the superior risk spreading that would result. Unfortunately, a more realistic view is that since identifying windfalls is itself very costly (as is the mechanism for spreading the gains or losses), the best we can do is to divide windfalls only between those parties who have a colorable legal claim to them.

\section{Force Majeure Clauses and Contractual Solutions to the Windfall Problem ${ }^{162}$}

Although the occurrence of $a$ war that, say, closes the Suez Canal might be unforeseeable to contracting parties, the occurrence of wars and other natural disasters is eminently foreseeable at a suitable level of generality. ${ }^{163}$ Hence, one might claim, contracting parties can deal

\footnotetext{
160 Id.

161 Id. at $1497-51$.

162 We are grateful to Paul Monteleoni for urging us to think carefully about these issues.

163 See supra note 61 and accompanying text.
} 
with risks that are individually unforeseeable through contractual provisions that aggregate such risks to a sufficiently general level such that it becomes worthwhile to allocate them despite the transaction costs of doing so. Although it may not be worth the cost to draft contractual language covering a particular remote risk, a collection of such risks might have a high enough expected value that parties would want to reach an agreement about who bears responsibility for them.

Such contractual allocation of broad-level risk is generally done under the rubric of a "force majeure" clause. These clauses are designed to absolve one or both contracting parties of responsibility for performance in the event that acts of God, war, natural disasters, unanticipated regulatory changes, or other unforeseeable acts make performance extremely onerous. ${ }^{164}$ Do these force majeure clauses render our approach to windfalls irrelevant, or in need of revision, in the contractual setting? Specifically, does the fact that parties rely on force majeure clauses instead of contracting for a splitting remedy warrant an inference that splitting is not an optimal solution? We answer both these questions in the negative.

Force majeure clauses do not effectively allocate responsibility for many windfalls that arise in contractual settings. Consider the problem of trying to write contractual language that would allocate the windfalls in the mutual mistake or ambiguous commitment cases we described earlier. Such risks are virtually impossible to characterize at a general level: Was it an act of God that caused the parties in Raffles to be confused about which ship named Peerless they were referring to? In Sherwood, was Rose's fertility a natural disaster? The ability to draft general language to allocate these risks is extremely limited.

Aside from these drafting problems, force majeure clauses are used only rarely in practice. Although it is difficult to generalize about real-world contracting behavior, a search of the Contracting and Organizations Research Institute (CORI) database revealed that only 2946 of 89,000-odd contracts in the database $(3.3 \%)$ contained a force majeure clause. ${ }^{165}$ It is hard to see how something so little used can be relied on as a practical solution to the risk allocation problem.

164 See generally Joseph M. Perillo, Force Majeure and Hardship Under the Unidroit Principles of International Commercial Contracts, 5 Tul. J. INT'L \& Comp. L. 5 (1997) (providing definitions and extended analysis of force majeure and related doctrines of hardship and impracticability).

165 According to the CORI website:

Most of the contracts in the collection are executed agreements made available in public disclosure filings or filed with a regulatory agency. Currently, the collection is primarily drawn from filings with the U.S. Securities and Exchange Commission's (SEC's) EDGAR Database. The required disclosure 


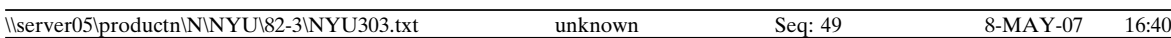

When they are used, moreover, force majeure clauses generally take the form of boilerplate language that simply parrots the default rules of impracticability. ${ }^{166}$ They specify that in the event of an unforeseen circumstance that renders performance impossible or impracticable, both parties are excused from having to perform, which is the default rule of the Restatement, ${ }^{167}$ U.C.C. ${ }^{168}$ and common law. ${ }^{169}$ To confirm this assertion, we randomly sampled twenty-nine (approximately 1\%) of the 2946 CORI contracts with an identifiable force majeure clause. Of these twenty-nine, only five of the force majeure clauses deviated from the default rules by excusing only one of the contracting parties. This suggests that only $0.6 \%{ }^{170}$ of the full sample had deviated from boilerplate force majeure clauses. This conclusion is consistent with that of Thomas Lundmark, who states that "a typical force majeure clause" excuses either party when its performance is prevented by a force majeure event, and that this result "merely restate[s] the existing law in all American jurisdictions." ${ }^{171}$ In practice, therefore, force majeure clauses do not deal with the problem of contractual windfalls any better than the default rules of impracticability. Rather, they generally replicate those rules, which, as we have argued, are deficient in their failure to recognize the desirability of a split-the-difference remedy.

The largely boilerplate nature of force majeure clauses can also help to reconcile our thesis that splitting windfall gains or losses is optimal with the apparent absence of a splitting remedy in any force majeure language. After all, if splitting is such a good idea, why is it

filings made by publicly traded companies frequently contain contracts that are of material interest to investors.

CORI: Contracting and Organizations Research Institute, http://cori.missouri.edu/pages/ ksearch.htm (last visited Mar. 28, 2007). Note that it is virtually impossible that the contracts in the CORI database represent a true random sample of the contractual universe, so any findings derived from these data must be interpreted as merely suggestive rather than statistically robust.

166 Excuse from performance under a force majeure clause is normally available to both parties equally: If either party finds itself in a force majeure situation, performance is excused. Such symmetry of excuse does not, however, translate into symmetrical allocation of risk. Consider a supplier of Congolese diamonds and a large American diamond buyer. The risk that a force majeure event (e.g., war, hurricane, military coup) will occur and prevent the Congolese seller from performing is much greater than the risk that the American buyer's performance will be prevented by similar events.

167 Restatement (Second) of Contracts $\$$ 261, 267 (1979); Farnsworth, supra note $84, \S 9.9$, at 642 .

168 See Perillo, supra note 61, at 555 (citing U.C.C. §§ 2-615 to -616 (2002)) (describing how U.C.C. excuse of impracticability facially applies only to seller, but at least one case has allowed excuse for buyer as well).

169 Perillo, supra note 164 , at 7.

$170(5 / 29)(2946 / 89,000)=0.6 \%$.

171 Thomas Lundmark, Verbose Contracts, 49 Aм. J. Comp. L. 121, 127-28 (2001). 
that private parties do not contract for it themselves? The answer is that the transaction costs of moving from the default rule to a splitthe-difference remedy, even for the aggregate of all unforeseeable risks, may be larger than the ex ante expected benefits of doing so. Boilerplate contract provisions can raise peculiar obstacles to the adoption of superior provisions, and in other contexts scholars have explained how suboptimal boilerplate provisions will persist due to context-specific path dependence ${ }^{172}$ or more general failure to perceive Coasean bargaining opportunities. ${ }^{173}$ The extent to which these factors explain the absence of split-the-difference remedies is an empirical question and beyond the scope of this paper. It is sufficient for our purposes to note that the absence of splitting in contractual practices is not fatal to our argument.

\section{E. Valuation Problems}

Courts are widely recognized to be institutionally weak when it comes to valuation. ${ }^{174}$ One virtue of an all-or-nothing remedy, therefore, is that no valuation is required: The court simply awards the disputed entitlement to the appropriate party without determining the entitlement's value. Under a splitting regime, however, the court will often find it necessary to divide the monetary value of the entitlement rather than the entitlement itself. ${ }^{175}$

Although a splitting solution does not eliminate valuation problems, there are reasons to believe that valuation for splitting will rarely pose a significant administrative challenge for courts. In some cases, the pre- and postwindfall values will be readily observable in thick markets. For example, in Sherwood, there was a market price for beef cattle, and a market price for breeding cattle. The court could thus easily observe the windfall by noting the difference between

172 John J. Donohue III, Opting for the British Rule, or If Posner and Shavell Can't Remember the Coase Theorem, Who Will?, 104 Harv. L. Rev. 1093, 1110, 1117-18 (1991) (attributing parties' failure to contract "rule shifts" for favorable allocation of attorneys' fees to failure to perceive Coasean bargaining opportunities).

173 Michelle E. Boardman, Contra Proferentem: The Allure of Ambiguous Boilerplate, 104 Мich. L. REv. 1105, 1113-17 (2006) (recognizing that where drafters-such as insurers-are more concerned that boilerplate provisions have fixed meaning rather than particular meaning, judicial interpretation of boilerplate language can lead to path dependence, causing admittedly inefficient provisions to continue to appear in new contracts).

174 See, e.g., Robert Cooter \& Thomas Ulen, Law and Economics 105 (4th ed. 2004) ("Injunction is traditionally regarded [as] clearer and simpler than damages, because the determination of damages by courts can be unpredictable.").

175 In Popov v. Hayashi, for example, the court did not physically divide the baseball in two and give half to each of the parties. Instead, it prescribed that the ball be sold and that the proceeds be split equally between the plaintiff and the defendant. Popov v. Hayashi, No. 400545, 2002 WL 31833731, at *8 (Cal. Super. Ct. Dec. 18, 2002). 


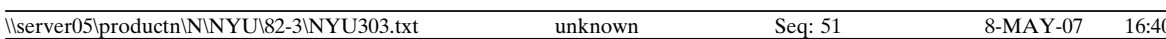

Rose's value as a breeder and as stew meat. Even in the absence of an ongoing market, judges could call for an auction as a way to elicit an acceptable valuation (as in Popov). In other cases, courts may find that the valuation exercise is more difficult because of idiosyncratic subjective value problems or thin markets. Still, courts confront these kinds of valuation issues all the time-for example, in deciding how much to award for pain and suffering - and there is nothing unique about the windfall setting that makes these problems any more difficult.

Moreover, in some instances, there will be an easily administered algorithm for splitting the windfall: a "take-or-pay" regime. Take-orpay would work as follows. Suppose the court in Sherwood recognized that Rose was much more valuable as a breeding cow than as stew meat but could not determine her price. A simple solution would be to randomly designate one party, $A$, to pick a value for Rose. The other party, $B$, would then be able to buy the cow for half of $A$ 's stated value. If $B$ declined to buy, $B$ would receive half of $A$ 's stated value instead. For example, suppose the original owner were designated as the price-setter. If he named a price of $\$ 2000$, the frustrated buyer could buy the cow for $\$ 1000$; if the buyer was not interested in purchasing at that price, the original owner could keep the cow but would have to pay $\$ 1000$ - half of his stated valuation-to the buyer.

The take-or-pay mechanism thus allows for splitting without the court having to put a monetary value on any entitlement. Moreover, it insures that neither party to the dispute ends up with less than half of its subjective valuation of the entitlement in question. ${ }^{176}$

\section{CONCLUSION}

This Article makes the case for a split-the-difference remedy for windfalls in contracts, torts, and property. We demonstrate that in cases of positive and negative windfalls, an equal division of the gain or loss between the parties is both more fair and more efficient than assigning the full gain or loss to one of the parties. By contrast with other legal disputes, the allocation of windfalls has no effect on the behavior of future parties. Splitting windfall gains and losses provides

176 Of course, if the price-setter acts irrationally or mistakenly, her stated price may be too high or too low. In the absence of irrationality or mistake, however, the price-setter has strong incentive to state a correct valuation. To illustrate, suppose both $A$ and $B$ knew that Rose's true value as a breeding cow was $\$ 800$. If $A$, as price-setter, set the cow's value at $\$ 10,000$, then $B$ would accept payment. Instead of an $\$ 800 \mathrm{cow}, B$ would have $\$ 5000$ cash. $A$, on the other hand, would keep the cow, but have to pay $B$ the $\$ 5000$, incurring a net loss of $\$ 4200$. Conversely, if $A$ set the value at $\$ 700$, then $B$ would opt to purchase the cow for $\$ 350$, leaving $A$ with a net loss of $\$ 50$. 
the parties with limited insurance against windfalls and establishes the Nash equilibrium of the hypothetical bargain between the parties. In addition, the introduction of a splitting option in such cases will enhance doctrinal and judicial integrity and bring much needed coherence to some nettlesome doctrines of private law. This Article further demonstrates that the standard arguments against splitting the difference do not withstand scrutiny. Splitting is likely to reduce judicial error costs and improve public trust in the judicial system.

It would have been natural to end with a call for adding a splitting remedy to the menu of judicial options, but such a call is unnecessary. The splitting option is already available to sufficiently creative judges in many contexts, as was demonstrated by Popov. Our goal in this Article, therefore, is to provide the theoretical rationale for splitting and to define its limits. We submit that the use of splitting under the conditions we identified will be beneficial for all parties involved. 